\title{
Carbon and helium isotopes in thermal springs of La Soufrière volcano (Guadeloupe, Lesser Antilles): Implications for volcanological monitoring
}

\author{
L. Ruzié ${ }^{\mathrm{a}, *}$, C. Aubaud ${ }^{\mathrm{b}}$, M. Moreira ${ }^{\mathrm{a}}$, P. Agrinier ${ }^{\mathrm{b}}$, C. Dessert ${ }^{\mathrm{a}}$, C. Gréau ${ }^{\mathrm{a}}$, O. Crispi ${ }^{\mathrm{c}}$ \\ a Équipe de Géochimie et Cosmochimie, Institut de Physique du Globe de Paris, Sorbonne Paris Cité, Univ Paris Diderot, UMR 7154 CNRS, F-75005 Paris, France \\ b Équipe de Géochimie des Isotopes Stables, Institut de Physique du Globe de Paris, Sorbonne Paris Cité, Univ Paris Diderot, UMR 7154 CNRS, F-75005 Paris, France \\ c Observatoire Volcanologique et Sismologique de Guadeloupe (OVSG) IPGP, UMR 7154 CNRS, Le Houëlmont, 97113 Gourbeyre, Guadeloupe (F.W.I.), France
}

\section{A R T I C L E I N F O}

\section{Article history:}

Received 28 November 2012

Received in revised form 6 September 2013

Accepted 12 September 2013

Available online 2 October 2013

Editor: David R. Hilton

\section{Keywords:}

Helium isotopes

Carbon isotopes

Volcanic hydrothermal system

La Soufrière

Guadeloupe

Lesser Antilles

\begin{abstract}
A B S T R A C T
La Soufrière (Guadeloupe, Lesser Antilles) is one of the most active and dangerous volcanoes of the Lesser Antilles arc. The renewal of the volcanic activity at La Soufrière requires replenishment of the volatile-poor andesitic stored magma with more primitive, volatile-rich basaltic magma. This event will trigger early release of large quantities of highly volatile species, like $\mathrm{CO}_{2}$ and helium, in the hydrothermal system. To use these precursors, first their baseline abundances and their behaviour in the hydrothermal system must be known during the current phase of dormancy. In this study, we have combined a previous systematic investigation of noble gases with carbon data of hydrothermal fluids flowing out of La Soufrière.

The results for dissolved gases reveal that an intense interaction between rising magmatic volatiles and groundwaters currently takes place at La Soufrière. We show that the pristine magmatic composition, with a ${ }^{13} \mathrm{C}_{\mathrm{CO} 2}$ value of $-3.19 \pm 0.03 \%$, a ${ }^{3} \mathrm{He} /{ }^{4} \mathrm{He}$ ratio of $8.1 \pm 0.2 \mathrm{R}_{\mathrm{a}}$ and a $\mathrm{CO}_{2} /{ }^{3} \mathrm{He}$ ratio of $1.03 \pm 0.18 \times 10^{10}$, may vary during the ascent of magmatic fluids due to either fractionation or mixing processes with meteoric water and/or an organic component. Here, we provide a baseline for $\mathrm{CO}_{2}$ and helium isotopes at each monitored spring and describe the superficial processes affecting both elemental and isotopic ratios.
\end{abstract}

Crown Copyright @ 2013 Published by Elsevier B.V. All rights reserved.

\section{Introduction}

The most recent eruptive activity at La Soufrière (Guadeloupe Island, Lesser Antilles) was a phreatic eruption in 1976-77 (Feuillard et al., 1983; Komorowski et al., 2005). That event led to the evacuation of 73,000 people living in the vicinity of the volcano for six months. La Soufrière remains one of the most active and dangerous volcanoes of the Lesser Antilles arc and the potential for any new unrest raises concerns regarding the safety of the growing population (Komorowski et al., 2005).

The Volcanological and Seismological Observatory of Guadeloupe (hereafter OVSG) monitors the volcano through a broad geophysical and geochemical network. Monthly hydrothermal fluid sampling provides information on the temporal changes in the magmatic system (OVSG-IPGP, 1978-2012). In fact, the well-established hydrothermal system of La Soufrière continually incorporates the rising magmatic fluids degassed by the magma chamber. However, superficial hydrothermal processes (e.g.: late degassing, mixing, water-

\footnotetext{
* Corresponding author at: School of Earth, Atmospheric and Environmental Sciences, The University of Manchester, Oxford Road, Manchester M13 9PL, UK. E-mail address: lorraine.ruzie@manchester.ac.uk (L. Ruzié).
}

rock interactions) can affect those deep fluids (Federico et al., 2002; Di Napoli et al., 2009).

In this study, we focus on the processes affecting each hydrothermal manifestation located on the volcano using both $\mathrm{CO}_{2}$ and helium and their isotopes, as tracers. Our aim is to refine our understanding of the hydrothermal system, which plays a critical role in the activity of La Soufrière. Carbon dioxide is the least soluble species in magmas (Dixon and Stolper, 1995). Therefore, the deep exsolution of this species and its low solubility in hydrothermal systems imply that carbon systematics is ideally suited to monitor the magmatic component injected into the system. However, $\mathrm{CO}_{2}$ exsolution, precipitation as calcite and biogenic contributions can disturb its budget. Therefore, a second tracer, which is not affected by these processes, should be considered. Owing to their high incompatibilities in magma, low concentrations and unreactive nature, the noble gases measured in hydrothermal fluids supplement the information provided by the carbon data. Also, the $\mathrm{CO}_{2} /{ }^{3} \mathrm{He}$ ratio can be used to distinguish between observed variations coming from the magmatic source and any variations due to the hydrothermal effects (e.g. Allard et al., 1997; Federico et al., 2002).

Here, we combine previous published noble gases data (Ruzié et al., 2012) with carbon data from hydrothermal springs and fumaroles sampled at the same time at La Soufrière over a 3 year period. Ruzié 
et al. (2012) focused on magmatic degassing processes through the use of noble gas tracers. No attention was given to the hydrothermal system. This decision was due to the fact that helium and neon have similar solubilities in water (e.g. Fernandez-Prini et al., 2003) which renders them inappropriate to describe the superficial processes such as degassing. By coupling carbon with helium/neon data, the range of solubilities increases, as well as the sensitivity to superficial processes. With both elemental and isotopic ratios, we propose a model of fluid circulation under the present non-eruptive conditions that could serve as a baseline for geochemical monitoring of the volcano.

\section{Geological setting}

\subsection{Volcanological activity}

The island of Guadeloupe is located in the Lesser Antilles island arc (Fig. 1A). La Soufrière volcano, located in the southern part of BasseTerre, is the only active volcanic centre on the island. It is an andesitic explosive volcano with past activity characterised by Pelean and Plinian eruptions (Boudon et al., 1989). The last magmatic eruption occurred 560 years ago (Boudon et al., 2008).

Since 1635 , only phreatic eruptions occurred in 1690, 1797-1798, 1836-1837, 1956, 1976-1977 (Komorowski et al., 2005). The triggering of the last phreatic eruption (1976-77) is still debated: aborted magmatic eruption (Feuillard et al., 1983; Villemant et al., 2005; Boichu et al., 2008, 2011) versus pure hydrothermal control (Zlotnicki et al., 1992). Recently, Ruzié et al. (2012) proposed that this last phreatic eruption was triggered by both: the emplacement of a new magma batch in the magmatic chamber around 1959-1962 followed by a progressive clogging of the hydrothermal system. This new scenario is based on the fact that the actual ${ }^{3} \mathrm{He}$ flux at the Central South Crater (CSC) Fumarole (0.02 mol/year) cannot be sustained since the last magmatic eruption. Ruzié et al. (2012) concluded that the actual magmatic chamber (located at $6 \mathrm{~km}$ depth) must be regularly fed by fresh basaltic magma batches.

After a period of relatively low activity (1984-1992), fumarolic manifestations increased in 1992 in a period also marked by a seismic crisis and the reactivation of two thermal springs (Zlotnicki et al., 1994; Boichu et al., 2011; OVSG-IPGP, 1978-2012). In 1998, the fumarolic condensates became more acidic due to chlorine degassing as $\mathrm{HCl}$. This was followed by reactivation of dome summit fumaroles at South Crater (1998), at Napoleon (2000), at Tarissan (2002) (Bernard et al., 2006; Nicollin et al., 2006, 2007) and more recently, Gouffre 1956 (2007), while the dome flank fumaroles at la Route de la Citerne progressively vanished (OVSG-IPGP, 1978-2012; Allard et al., 1998).

\subsection{Hydrothermal system}

The hydrothermal system of La Soufrière is composed of a main aquifer with restricted size delimited by the Amic caldera borders (Barat, 1986). This aquifer is fed by meteoric water percolating through recent pyroclastic deposits (Bigot et al., 1994b; Brombach et al., 2000; Pascaline et al., 1982; OVSG-IPGP, 1978-2012). The main aquifer is also subjected to a gas flux derived from an underlying degassing magma chamber (Villemant et al., 2005; Ruzié et al., 2012). The roof of this main aquifer is thought to be located at a depth of $500 \mathrm{~m}$ under the dome summit and its temperature is between $190^{\circ} \mathrm{C}$ and $260^{\circ} \mathrm{C}$ (Brombach et al., 2000). This main aquifer is therefore most likely continually boiling. These temperatures are also in good agreement with the hydrothermal mineral assemblages observed in debris avalanche deposits of La Soufrière (smectite + silica \pm pyrite \pm natrojarosite). This assemblage is formed at temperatures below $300^{\circ} \mathrm{C}$ (Salaün et al., 2011). The dome is made of unaltered massive andesite lava separated by major radial fractures as demonstrated by both electrical tomography (Nicollin et al., 2006) and VLF survey (Zlonicki et al., 2006). Numerous low-density parts of highly hydrothermalized and unconsolidated materials (Lesparre et al., 2012) could also contain small shallow aquifers, feeding the thermal springs.

The distribution of the thermal springs on La Soufrière is controlled by geological structures (Fig. 1B). Seven thermal springs are located in the Amic Crater at high altitudes (1146-981 m) and at a maximum distance of $1.2 \mathrm{~km}$ from the lava dome: Ravine Marchand (RM3), Galion (GA), Galion Bas (GAB), Carbet-Echelle (CE), Bains Jaunes (BJ), Pas du Roy (PR) and Tarade (TA). One spring, Bains Chauds du Matouba (BCM), is located outside the Amic Crater but still in La Grande Découverte Caldera. Finally, two springs lie outside La Grande Découverte Caldera: one on the eastern flank of the volcano, Chute du Carbet (CC), at $2.1 \mathrm{~km}$ from the

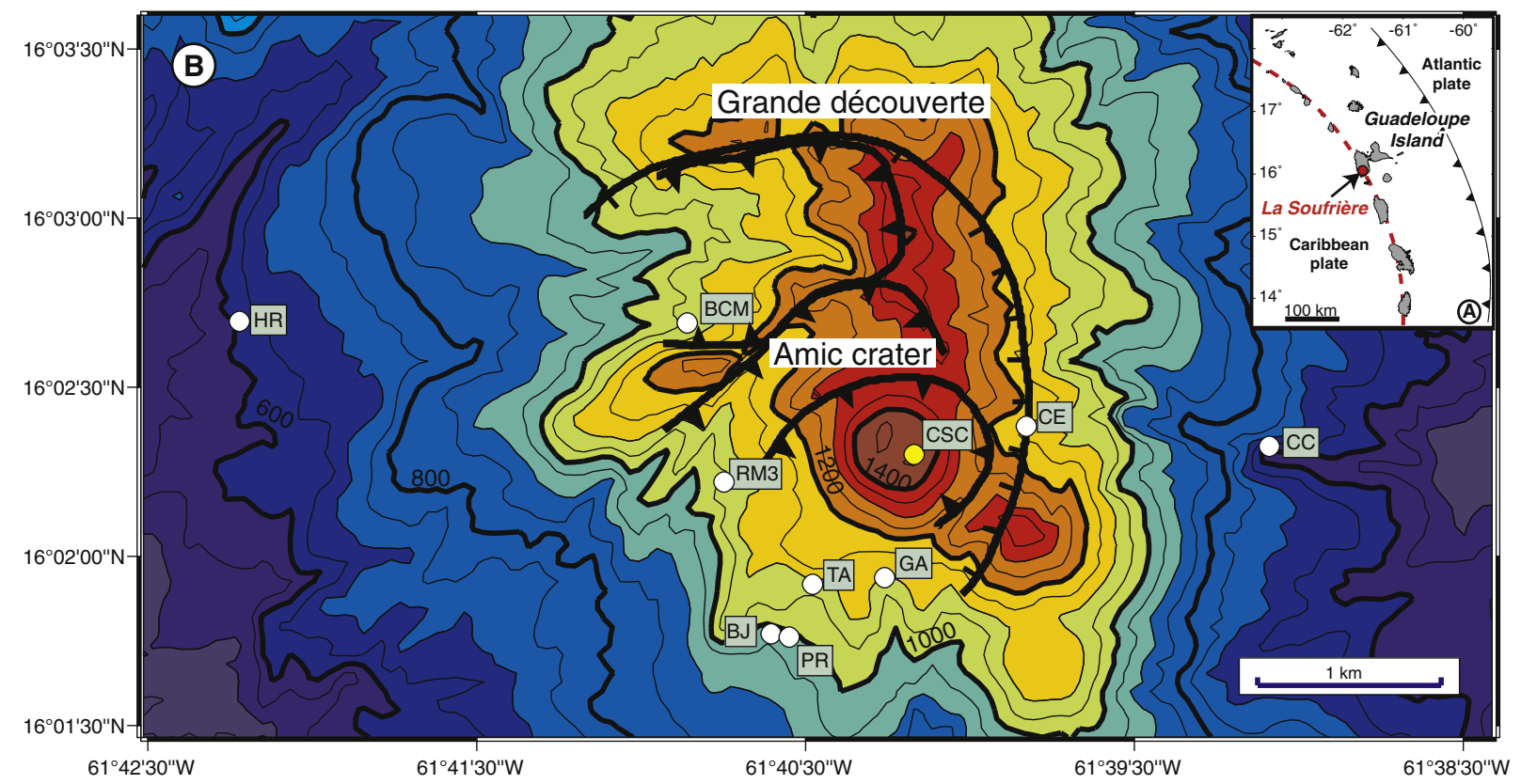

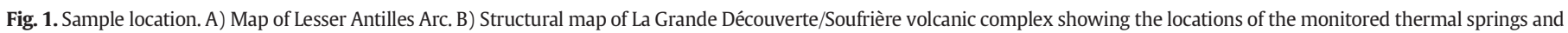
South Crater (CSC) fumarole. 
Table 1

Helium and carbon isotopic compositions of dissolved gases in La Soufrière volcano thermal springs.

\begin{tabular}{|c|c|c|c|c|c|c|c|c|c|c|c|c|c|c|c|c|c|c|}
\hline $\begin{array}{l}\text { Sample } \\
\text { name }\end{array}$ & $\begin{array}{l}\text { Sampling } \\
\text { date }\end{array}$ & $\begin{array}{l}\text { Sample } \\
\text { type }\end{array}$ & $\begin{array}{l}\text { Dome distance } \\
(\mathrm{m})\end{array}$ & $\begin{array}{l}\text { Alt. } \\
\text { (m) }\end{array}$ & $\begin{array}{l}\text { Temp. } \\
\left({ }^{\circ} \mathrm{C}\right)\end{array}$ & $\mathrm{pH}$ & {$\left[\mathrm{R}_{\mathrm{m}} / \mathrm{R}_{\mathrm{a}}\right]^{1}$} & $\sigma$ & ${ }^{4} \mathrm{He} /{ }^{22} \mathrm{Ne}$ & $\sigma$ & {$\left[\mathrm{R}_{\mathrm{c}} / \mathrm{R}_{\mathrm{a}}\right]^{2}$} & $\sigma$ & ${ }^{3} \mathrm{He}\left(\times 10^{-14} \mathrm{ccSTP} / \mathrm{g}\right)$ & $\mathrm{X}_{\mathrm{m}^{3}}$ & $\begin{array}{l}\text { TDIC } \\
(\mathrm{mmol} / \mathrm{l})\end{array}$ & $\begin{array}{l}{\left[\mathrm{TDIC}_{\mathrm{i}}\right]^{4}} \\
(\mathrm{mmol} / \mathrm{l})\end{array}$ & $\begin{array}{l}\delta^{13} C^{5} \\
(\%)\end{array}$ & $\begin{array}{l}\mathrm{CO}_{2} /{ }^{3} \mathrm{He} \\
\left(\times 10^{10}\right)\end{array}$ \\
\hline \multicolumn{19}{|l|}{ Bains Jaunes } \\
\hline GUA07_BJ & Jul-07 & \multirow{3}{*}{$\mathrm{Ca}-\mathrm{SO}_{4}$ water } & \multirow{3}{*}{1200} & \multirow{3}{*}{981} & 31.4 & 5.6 & 1.02 & 0.10 & 3.0 & 0.2 & - & - & 7 & $12 \%$ & 0.86 & & -5.10 & 29 \\
\hline GUA09_BJ & May-09 & & & & 33.9 & 5.5 & 1.38 & 0.04 & 3.1 & 0.2 & - & - & 9 & $17 \%$ & 1.56 & & -7.83 & 40 \\
\hline GUA10_BJ & Oct-10 & & & & 29.4 & 5.4 & 1.40 & 0.06 & 2.9 & 0.1 & - & - & 8 & $17 \%$ & 2.21 & & -4.97 & 59 \\
\hline \multicolumn{19}{|c|}{ Bains Chauds du Matouba } \\
\hline GUA07_BCM & Jul-07 & $\mathrm{Ca}-\mathrm{SO}_{4}$ water & 1250 & 1055 & 58.5 & 5.9 & 4.38 & 0.31 & 5.1 & 0.3 & 8.0 & 0.8 & 102 & $99 \%$ & 0.79 & & -10.04 & 1.7 \\
\hline \multicolumn{19}{|l|}{ Carbet Echelle } \\
\hline GUA07_CE & Jul-07 & \multirow{2}{*}{$\mathrm{Ca}-\mathrm{SO}_{4}$ water } & \multirow[t]{2}{*}{640} & \multirow[t]{2}{*}{1146} & 20.9 & 5.4 & 6.61 & 0.45 & 12.3 & 0.8 & 8.1 & 0.6 & 162 & $100 \%$ & 5.59 & 8.59 & -2.87 & 12 \\
\hline GUA09_CE & May-09 & & & & 20.3 & 5.4 & 6.55 & 0.11 & 13.6 & 0.7 & 8.2 & 0.2 & 176 & $100 \%$ & 6.58 & 11.09 & -2.80 & 14 \\
\hline \multicolumn{19}{|c|}{ Central South Crater Fumarole } \\
\hline GUA07_CSC & May-07 & \multirow{2}{*}{ Fumarole } & \multirow[t]{2}{*}{0} & \multirow{2}{*}{1476} & 120 & 0.7 & 7.80 & 0.20 & 442 & 3 & 7.9 & 0.2 & a & $99 \%$ & a & & -3.17 & 1.2 \\
\hline GUA09_CSC & Oct-10 & & & & 97.9 & 2.0 & 7.60 & 0.30 & 56.3 & 1.0 & 8.2 & 0.4 & b & $100 \%$ & b & & -3.21 & 0.9 \\
\hline \multicolumn{19}{|c|}{ Chute du Carbet } \\
\hline GUA07_CC & Jul-07 & \multirow{2}{*}{$\mathrm{Ca}-\mathrm{Na}-\mathrm{Cl}$ water } & \multirow{2}{*}{2100} & \multirow[t]{2}{*}{605} & 44.5 & 6.6 & 5.22 & 0.36 & 9.8 & 0.7 & 6.8 & 0.5 & 103 & $84 \%$ & 3.24 & 3.74 & -2.95 & 8.2 \\
\hline GUA10_CC & Oct-10 & & & & 44.7 & 6.6 & 4.88 & 0.18 & 9.2 & 0.2 & 6.4 & 0.3 & 108 & $79 \%$ & 3.89 & 4.80 & -2.73 & 9.8 \\
\hline \multicolumn{19}{|l|}{ Galion bas } \\
\hline GUA07_GAB & Jul-07 & \multirow{3}{*}{$\mathrm{Ca}-\mathrm{SO}_{4}$ water } & \multirow{3}{*}{760} & \multirow{3}{*}{1100} & 41.4 & 4.8 & 6.76 & 0.47 & 15.1 & 1.0 & 8.0 & 0.6 & 60 & $99 \%$ & 7.45 & & -3.00 & 28 \\
\hline GUA09_GAB & May-09 & & & & 41.6 & 4.7 & 5.27 & 0.10 & 8.2 & 0.4 & 7.3 & 0.2 & 37 & $90 \%$ & 5.22 & & -3.00 & 32 \\
\hline GUA10_GAB & Oct-10 & & & & 42.8 & 4.9 & 5.94 & 0.22 & 10.1 & 0.3 & 7.7 & 0.3 & 51 & $95 \%$ & - & & - & - \\
\hline Galion & & & & & & & & & & & & & & & & & & \\
\hline GUA07_GA & Jul-07 & & & & 45.7 & 4.8 & 5.91 & 0.42 & 10.6 & 0.7 & 7.5 & 0.6 & 39 & $93 \%$ & 8.97 & & -3.39 & 52 \\
\hline GUA09_GA & May-09 & $\mathrm{Ca}-\mathrm{SO}_{4}$ water & 760 & 1100 & 45.8 & 4.7 & 5.47 & 0.11 & 9.4 & 0.5 & 7.2 & 0.2 & 35 & $89 \%$ & 7.43 & & -3.37 & 48 \\
\hline GUA10_GA & Oct-10 & & & & 45.9 & 5.0 & 5.35 & 0.20 & 8.9 & 0.3 & 7.2 & 0.3 & 41 & $89 \%$ & - & & - & - \\
\hline Tarade & & & & & & & & & & & & & & & & & & \\
\hline GUA09_TA & May-09 & C. 80 untor & 1000 & 1079 & 41.4 & 6.0 & 3.75 & 0.07 & 5.2 & 0.1 & 6.5 & 0.2 & 36 & $80 \%$ & 4.36 & 6.36 & -2.63 & 40 \\
\hline GUA10_TA & Oct-10 & $\mathrm{Ca}-\mathrm{SO}_{4}$ water & & & 39.4 & 6.1 & 3.49 & 0.14 & 4.1 & 0.1 & 8.0 & 0.6 & 27 & $99 \%$ & 2.98 & 3.98 & -2.55 & 34 \\
\hline Pas du Roy & & & & & & & & & & & & & & & & & & \\
\hline GUA07_PR & Jul-07 & & & & 34.0 & 5.6 & 2.77 & 0.20 & 3.7 & 0.3 & 7.1 & 1.2 & 51 & $88 \%$ & 3.28 & & -3.01 & 38 \\
\hline GUA09_PR & May-09 & $\mathrm{Ca}-\mathrm{SO}_{4}$ water & 1200 & 1008 & 33.9 & 5.6 & 2.88 & 0.06 & 3.8 & 0.2 & 7.0 & 0.7 & 49 & $86 \%$ & 3.26 & & -3.27 & 36 \\
\hline GUA10_PR & Oct-10 & & & & 34.2 & 5.8 & 2.65 & 0.10 & 3.7 & 0.1 & 6.5 & 0.5 & 51 & $80 \%$ & & & - & - \\
\hline Habitation Reve & & & & & & & & & & & & & & & & & & \\
\hline GUA09_HR & May-09 & & 3700 & 609 & 31.2 & 6.8 & 4.51 & 0.08 & 10.1 & 0.5 & 5.7 & 0.1 & 89 & $70 \%$ & 2.83 & & -18.11 & 7.1 \\
\hline GUA10_HR & Oct-10 & $\mathrm{Ca}-\mathrm{Na}-\mathrm{HCO}_{3}$ water & & & 33.4 & 6.7 & 3.49 & 0.13 & 5.5 & 0.1 & 5.8 & 0.3 & 43 & $71 \%$ & & & - & - \\
\hline Ravine Marcha & $d 3$ & & & & & & & & & & & & & & & & & \\
\hline GUA07_RM3 & Jul-07 & & & & 44.9 & 5.2 & 7.66 & 0.52 & 36.6 & 2.5 & 8.2 & 0.6 & 197 & $100 \%$ & 3.81 & 10.81 & -2.11 & 11 \\
\hline GUA09_RM3 & May-09 & $\mathrm{Ca}-\mathrm{SO}_{4}$ water & 950 & 1015 & 48.4 & 5.2 & 7.54 & 0.13 & 43.1 & 1.3 & 8.0 & 0.1 & 211 & $99 \%$ & 8.33 & & -3.19 & 8.9 \\
\hline GUA10_RM3 & Oct-10 & & & & 42.9 & 5.5 & 7.45 & 0.27 & 32.6 & 0.8 & 8.0 & 0.3 & 225 & $99 \%$ & & & - & - \\
\hline
\end{tabular}

1. $\mathrm{R}_{\mathrm{m}}:{ }^{3} \mathrm{He} /{ }^{4} \mathrm{He}$ ration measured; $\mathrm{R}_{\mathrm{d}}$ : ratio of air $\left(1.4 \times 10^{-6}\right)$.

2. $R_{c}$ : air corrected helium isotopic ratio, assuming all the neon is derived from air (Poreda and Craig, 1989).

3. $\mathrm{X}_{\mathrm{m}}$ : percent of the local magmatic end-member based on the calculation of Eq. (9).

4. TDIC $\mathrm{i}$ : TDIC corrected for the $\mathrm{CO}_{2}$ degassing (see text for more details).

5. Accuracy is $\pm 0.04 \%$ for TDIC greater than $2 \mathrm{mmol} / \mathrm{l}$ and $\pm 0.20 \%$ for TDIC lower than $2 \mathrm{mmol} / \mathrm{l}$. N.B.: For the gas samples accuracy is $\pm 0.3 \%$.

b GUA10_CSC (dry gas): $[\mathrm{He}]=6.78 \mathrm{ppm},\left[\mathrm{CO}_{2}\right]=66.43 \%$. 
dome summit and one in the western part at $3.7 \mathrm{~km}$ (Habitation Revel HR) (Table 1).

Three types of thermal waters are identified around La Soufrière dome (OVSG-IPGP, 1978-2012; Pascaline et al., 1982; Brombach et al., 2000; Villemant et al., 2005): a) Ca-SO $\mathrm{S}_{4}$ waters produced by mixing of meteoric water and rising magmatic fluids (BCM, BJ, PR, CE, GA, GAB, $\mathrm{RM} 3, \mathrm{TA}$ ); b) $\mathrm{Ca}-\mathrm{Na}-\mathrm{HCO}_{3}$ springs which are conductively heated $(\mathrm{HR})$ and c) $\mathrm{Ca}-\mathrm{Na}-\mathrm{Cl}$ waters interpreted as a mixture of $\mathrm{Ca}-\mathrm{SO}_{4}$ waters and $\mathrm{Na}-\mathrm{Cl}$ waters $(\mathrm{CC})$ (Table 1 ).

Based on major elements and oxygen isotopes, Brombach et al. (2000) defined two settings of the thermal springs at La Soufrière: 1) a central area dominated by the ascent of steam which is extracted from the main aquifer. The steam feeds the summit fumaroles or dissolves in shallow aquifers and 2) an outer zone, where the groundwaters are heated through conduction. For the superficial aquifers hosted in the dome flanks, Villemant et al. (2005) developed a model of fluid circulation using chlorine concentration data recorded since 1979 by the OVSG. The evolution of the chlorine content seems to be related to the location of the springs: the magmatic chlorine signal, injected as pulses, get smoothed and delayed while the distance to the dome increases.

Finally, Van Soest et al. (1998) and Pedroni et al. (1999) reported carbon and noble gas data for springs and fumaroles from several islands of the Lesser Antilles. While their studies are useful at the scale of the arc, La Soufrière of Guadeloupe has been poorly sampled in terms of thermal springs. Therefore, a more detailed and focused study is needed to describe the interactions between the magmatic fluids and the superficial processes that could modify the pristine magmatic signal. We propose to improve our understanding of the
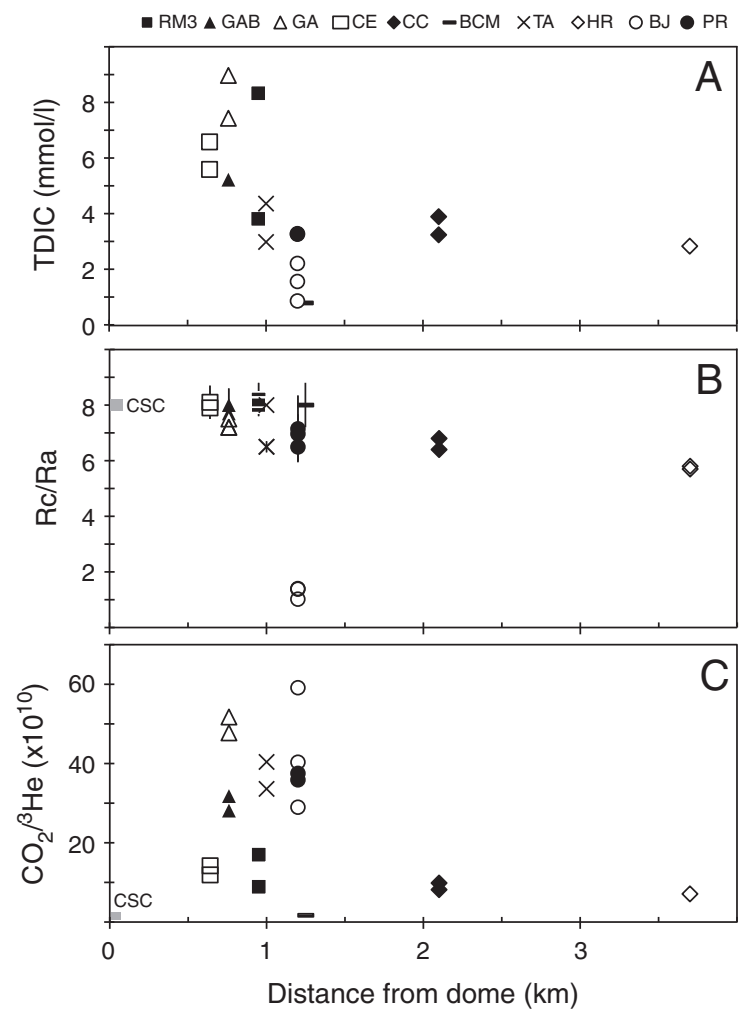

Fig. 2. Carbon and helium variations as a function of the dome distance. A) TDIC (Total Dissolved Inorganic Carbon), B) $R_{c} / R_{a}$ ratio $\left(R_{c}=\left[{ }^{3} \mathrm{He} /{ }^{4} \mathrm{He}\right]_{\text {corrected }} ; R_{a}=\left[{ }^{3} \mathrm{He}\right.\right.$ $\left.{ }^{4} \mathrm{He}\right]_{\mathrm{air}}=1.4 \times 10^{-6}$ ) and C) $\mathrm{CO}_{2} /{ }^{3} \mathrm{He}$ versus distance from the dome. The TDIC concentrations and $R_{c} / R_{a}$ ratio in thermal springs decrease with increasing distance from the dome centre. No trend seems to appear between $\mathrm{CO}_{2} /{ }^{3} \mathrm{He}$ ratio as a function of the dome distance. $\mathrm{RM} 3=$ Ravine Marchand, $\mathrm{GAB}=$ Galion Bis, $\mathrm{GA}=$ Galion, $\mathrm{CE}=$ Carbet Echelle, $\mathrm{CC}=$ Chute du Carbet, $\mathrm{BCM}=$ Bains Chauds du Matouba, $\mathrm{TA}=$ Tarade, $\mathrm{HR}=$ Habitation Revel, BJ = Bains Jaunes and PR = Pas du Roy.

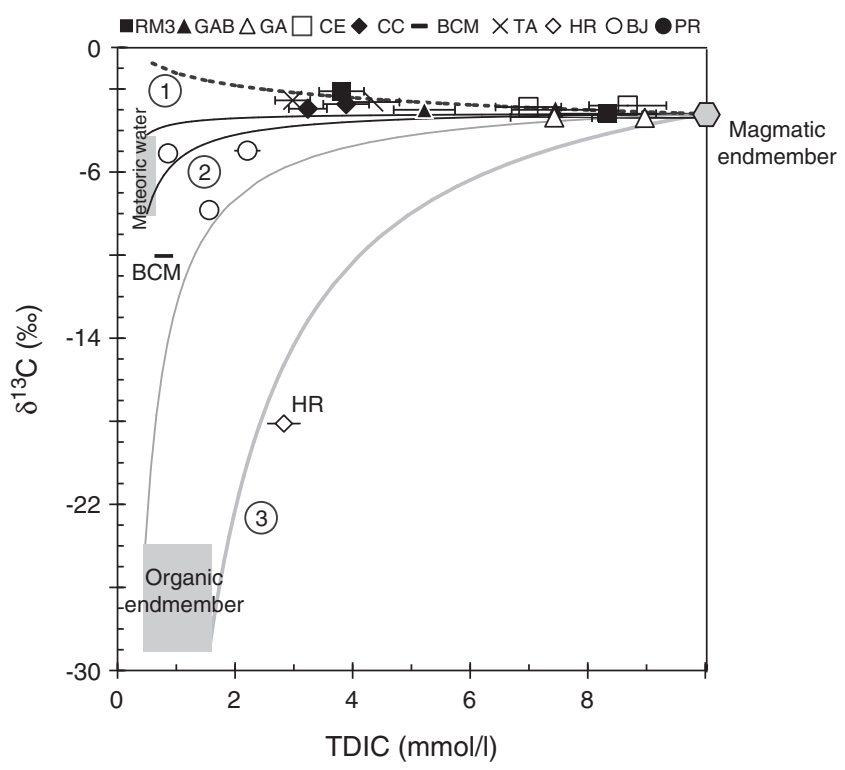

Fig. 3. Isotopic composition of dissolved $\mathrm{CO}_{2}$ in thermal waters of La Soufrière vs. the corresponding TDIC ( $\mathrm{mmol} / \mathrm{l}$ ). The Rayleigh distillation curve (1) is plotted in dashed line. The theoretical mixing curves between different end-members are plotted. The black solid curve (2) corresponds to a mixture between the local magmatic end-member $\left(\delta^{13} \mathrm{C}=-3.19 \pm 0.03 \%\right.$, TDIC $\left.=10 \mathrm{mmol} / \mathrm{l}\right)$ and the meteoric water $\left(\delta^{13} \mathrm{C}=-8.0 /-\right.$ $4.2 \%$, TDIC $=0.5 \mathrm{mmol} / \mathrm{l}$ ). The grey lines ( 3 and 4 ) reflect a mixture between the magmatic

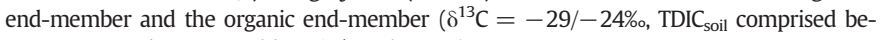
tween 0.47 and $1.56 \mathrm{mmol} / \mathrm{l}$ - Rivé et al., 2013).

hydrothermal system by coupling carbon and noble gas systematics under the present hydrothermal conditions.

\section{Field and laboratory methods}

In order to understand the superficial processes that could affect the magmatic signal, fluid samples for noble gas analyses were collected once per year (from 2007 to 2010) at 11 sites (Fig. 1B). In this study, we link to these samples to the corresponding carbon measurements.

\subsection{Water samples}

The water samples for total dissolved inorganic carbon measurements (hereafter TDIC which is defined as $\left[\mathrm{H}_{2} \mathrm{CO}_{3}\right]+\left[\mathrm{HCO}_{3}^{-}\right]+$ $\left[\mathrm{CO}_{3}^{2-}\right]$ ) were filtered in the field (filter size $0.2 \mathrm{~mm}$ ) and collected using Labco $12 \mathrm{ml}$ Exetainer vials with no headspace. The vials (hereafter storage vials) were then stored at $4{ }^{\circ} \mathrm{C}$ to limit bacterial development until their analysis. The method for TDIC and $\delta^{13} \mathrm{C}_{\text {TDIC- }}$ value measurements in water has been published previously in detail by Assayag et al. (2006) and is summarised here. The TDIC is released from the sample as $\mathrm{CO}_{2}$ by the $\mathrm{H}_{3} \mathrm{PO}_{4}$ acidification method as follows. Fifteen drops of $\mathrm{H}_{3} \mathrm{PO}_{4}$ are loaded in empty and uncapped 12-ml exetainers (hereafter analytical vial). The analytical vials are then isolated from the atmosphere by screwing a cap equipped with a septum on top of them. The analytical vials are then flushed with pure helium. A fixed quantity ( 2 or $5 \mathrm{ml}$ depending on the TDIC concentration of the sample) of the natural water sample is extracted with a syringe from the storage vial through the septum. This is accomplished by injecting an equivalent volume of pure helium into the storage vial with a second syringe while the first syringe is used to sample the water. The water is then injected into the analytical vial. Equilibration between $\mathrm{CO}_{2}$ in the gas phase and $\mathrm{CO}_{2}$ dissolved in the liquid is obtained by shaking during a period of 15-25 h (see Assayag et al., 2006 for the original tests regarding equilibration time). Two sets of standards are prepared: the first set for concentration determination and the second set for $\delta^{13} \mathrm{C}$ determination. The first set of standard is prepared from an initial solution of $\mathrm{NaHCO}_{3}$ (with a 
known $\delta^{13} \mathrm{C}$ ) that is then diluted by several factors. This is used for concentration determinations and corrections from non-linearity effects of the mass spectrometer (see details and Fig. 4 in Assayag et al., 2006). The second standard is then prepared with different $\mathrm{CaCO}_{3}$ powders with known $\delta{ }^{13} \mathrm{C}$-values. This set of standards is used for carbon isotope determination only. These two sets of standards are analysed before, in-between and after the unknowns to check for drifting analytical conditions of the gas chromatograph-isotope ratio mass spectrometer (GC-IRMS) system. The GC-IRMS system is a helium continuous flow mass spectrometer (GV AP2003C) equipped with a gas chromatograph (see description in Assayag et al., 2006). During the analysis, a fully automated autosampler equipped with a needle sequentially samples the gas $\left(\mathrm{CO}_{2}+\mathrm{He}+\right.$ traces of water vapour and atmospheric gases) in the headspace of the analytical vials. This mixture is then purified to remove water vapour, separated with a GC column and admitted to the source of the mass spectrometer. Concentrations are obtained by comparison of sample height with those of the $\mathrm{NaHCO}_{3}$ standards. $\delta^{13} \mathrm{C}$-values are obtained by first correcting the raw values from non-linearity effects and then comparing the corrected raw $\delta{ }^{13} \mathrm{C}$ values to those of the $\mathrm{CaCO}_{3}$ standards. Details of the procedures can be found in Assayag et al. (2006). TDIC concentrations are obtained with a relative uncertainty of $\pm 10 \%$. Analyses of a calcite standard (IAEA-CO-1) conducted during the period of this work and ran as an unknown were within analytical uncertainty of the accepted value $(+2.49 \% / \mathrm{VPDB})$ and reproducible to $\pm 0.04 \%$ 。 $(1 \mathrm{~s} ; \mathrm{n}=16)$ for TDIC greater than $2 \mathrm{mmol} / \mathrm{l}$ and $\pm 0.20 \%$ o $(1 \mathrm{~s} ; \mathrm{n}=6)$ for TDIC lower than $2 \mathrm{mmol} / \mathrm{l}$.

The water samples dedicated to noble gas analyses were collected using copper tubes sealed at both ends by steel clamps after repeated tube flushing. The measurements were conducted on a Quadrupole Mass-Spectrometer (QMG220, Pfeiffer@) for helium and neon concentrations and a Noblesse mass-spectrometer (Nu Instruments $($ ) ) for helium and neon isotopic ratios. The complete procedure is described in Ruzié et al. (2012).

\subsection{Gas samples}

The $\delta^{13} \mathrm{C}_{\mathrm{CO} 2}$ of CSC fumarole $\mathrm{CO}_{2}$ is measured on the dry fraction of the fumarolic gases sampled in pyrex bottles filled with $\mathrm{P}_{2} \mathrm{O}_{5}$. The $\mathrm{CO}_{2}$ is purified both cryogenically and by circulation over $\mathrm{CuO}$ maintained at $250{ }^{\circ} \mathrm{C}$ (notably to remove $\mathrm{H}_{2} \mathrm{~S}$ ). The $\delta^{13} \mathrm{C}$-value of the resulting purified $\mathrm{CO}_{2}$ is measured with a dual inlet massspectrometer (Thermofisher Delta Plus XP®) with a typical uncertainty of $\pm 0.03 \%$.

For the noble gas systematics, CSC fumarole was collected twice in April 2007 and October 2010 using the routine method of the observatory (Ruzié et al., 2012). The samples were analysed for all the noble gas on the glass mass-spectrometer ARESIBO II.

\section{Results}

\subsection{Carbon isotopes in fumaroles and springs}

The $\delta^{13} \mathrm{C}_{\mathrm{TDIC}}$ values of La Soufrière hydrothermal water range from $-18.11 \%$ o (HR) to $-2.11 \%$ (RM3) (Table 1 ). This range of values is similar to previously published data on La Soufrière (van Soest et al.,
1998; Pedroni et al., 1999; Rivé et al., 2013). The TDIC concentration of springs varies from $0.79(\mathrm{BCM})$ to $8.97(\mathrm{GA}) \mathrm{mmol} / \mathrm{l}$ and decreases with increasing distance from the dome centre (Fig. 2A). The carbon isotopic composition $\left(\delta^{13} \mathrm{C}\right)$ as a function of the TDIC concentration is represented in Fig. 3. At high TDIC ( $>3 \mathrm{mmol} / \mathrm{l})$, the spring data plot on a quasi-horizontal line anchored at the $\delta^{13} \mathrm{C}$ value $(=-3.19 \pm$ $0.03 \%, \mathrm{n}=2$ ) of the $\mathrm{CO}_{2}$ degassed by the summit fumarole. The fumarolic $\delta^{13} \mathrm{C}$ is compared to values measured in 1995 by Pedroni et al. (1999) and van Soest et al. (1998) (Table 2). We decided to consider our measurements in CSC fumarole as the isotopic signature of the local magmatic end-member. The low TDIC springs, $<3 \mathrm{mmol} / \mathrm{l}$, have lower $\delta^{13} C_{\text {TDIC }}$, down to $-18 \%$ ofor HR. These low $\delta^{13} C_{\text {TDIC }}$ values are common in volcanic areas and reflect the contribution of soil respired$\mathrm{CO}_{2}$ derived from bacterial degradation of organic matter and plant root respiration (Chiodini et al., 2000; Cartwright et al., 2002; Inguaggiato et al., 2005). Recently, Rivé et al. (213) estimated the organic component in Guadeloupe between -29.0 and $-24.0 \%$ with TDIC between 0.47 and $1.56 \mathrm{mmol} / \mathrm{l}$.

On a large scale, mixing modelling shows that all of the observed compositional range can be explained by variable contributions of a local magmatic component (LMC), diluted in the shallow groundwaters loaded with TDIC from the soil and/or air (Fig. 3). The $\delta^{13} C_{\text {TDIC }}$ value of meteoric water is unknown but can be calculated from the average atmospheric ${ }^{813} \mathrm{C}$ value ( -8.2 , see http://scrippsco2.ucsd.edu/data/ atmospheric_co2.html) and appropriate carbon isotopic fractionation factors (Deines et al., 1974; Mook et al., 1974). In coastal areas, the pH of rainwater varies from 5.5 to 6.5 (Negrel et al., 1997 for French Guiana). At $20{ }^{\circ} \mathrm{C}, \delta^{13} \mathrm{C}_{\mathrm{TDIC}}$ is enriched by $+0.2 \%$ ( at $\mathrm{pH}=5.5$ ) to $+4 \%$ ( at $\mathrm{pH}=6.5$ ) relative to $\mathrm{CO}_{2}$ resulting in a range of DIC from -8 to $-4.2 \%$.

On a smaller scale, we note that some springs have $\delta^{13} C_{\text {TDIC }}$ higher than the range defined for magmatic component $(\geq-3.19 \pm 0.03 \%$ ). Low TDIC values are systematically associated with high $\delta^{13} \mathrm{C}_{\mathrm{TDIC}}$ (Table 1). Degassing of $\mathrm{CO}_{2}$ could be responsible for a decrease in TDIC and an increase in $\delta^{13} \mathrm{C}$-value. The magnitude of the carbon isotope fractionation during this loss depends on the speciation of the dissolved carbon species $\left(\mathrm{H}_{2} \mathrm{CO}_{3}, \mathrm{HCO}_{3}^{-}, \mathrm{CO}_{3}^{2-}\right)$, which is in turn dependent on the $\mathrm{pH}$ of the water and on temperature (Mook et al., 1974; Mook et Koene, 1975). At low $\mathrm{pH}, \mathrm{H}_{2} \mathrm{CO}_{3}$ dominates and the bulk fractionation between $\mathrm{CO}_{2}$ and TDIC $\left(\delta^{13} \mathrm{C}_{\mathrm{CO} 2 \text {-TDIC }}\right)$ is $+1.1 \%$ o at $25{ }^{\circ} \mathrm{C}$. To assess the initial DIC content of the water, we have assumed conservation of alkalinity, this holds true if no carbonate minerals are precipitated or dissolved. Carbonated Saturation indexes are all below 1 showing the validity of this assumption (Rivé et al., 2013). For an open system degassing we may write a Rayleigh distillation law to describe the evolution of the isotopic composition of the DIC:

$\partial{ }^{13} \mathrm{C}_{\mathrm{DIC}} / \partial^{12} \mathrm{C}_{\mathrm{DIC}}=\alpha_{\mathrm{CO} 2-\mathrm{DIC}} *{ }^{13} \mathrm{C}_{\mathrm{DIC}} /{ }^{12} \mathrm{C}_{\mathrm{DIC}}$

In dissolved state, TDIC can be in the form of dissolved $\mathrm{CO}_{2}\left(\mathrm{H}_{2} \mathrm{CO}_{3}\right)$ or bicarbonate ions $\left(\mathrm{HCO}_{3}^{-}\right)$or carbonate ion $\left(\mathrm{CO}_{3}^{2-}\right)$ whose relative concentrations depend on the solution $\mathrm{pH}$. Thus, the general fractionation between DIC and $\mathrm{CO}_{2}$ in gaseous state is a linear combination of fractionation between each ionic form of dissolved $\mathrm{CO}_{2}$ and gaseous

Table 2

Helium and carbon elemental and isotopic compositions of CSC fumarole.

\begin{tabular}{|c|c|c|c|c|c|c|c|c|}
\hline Ref. & & Date & $\delta^{13} \mathrm{C}_{\mathrm{CO} 2}(\%)$ & \pm & ${ }^{3} \mathrm{He} /{ }^{4} \mathrm{He}(\mathrm{Ra})$ & \pm & $\mathrm{CO}_{2} /{ }^{3} \mathrm{He}\left(\times 10^{10}\right)$ & \pm \\
\hline van Soest et al., 1998 & $\mathrm{n}=2$ & 1995 & -3.15 & 0.07 & 7.95 & 0.01 & 1.16 & 0.01 \\
\hline Pedroni et al., 1999 & $\mathrm{n}=2$ & 1995 & -3.02 & 0.01 & 8.40 & 0.10 & 1.29 & 0.62 \\
\hline This study & $\mathrm{n}=2$ & 2007 and 2010 & -3.19 & 0.03 & 8.05 & 0.21 & 1.03 & 0.18 \\
\hline Average & & & -3.12 & 0.09 & 8.13 & 0.24 & 1.16 & 0.13 \\
\hline
\end{tabular}


$\mathrm{CO}_{2}:$

$$
\begin{aligned}
\mathrm{DIC} * \alpha_{\mathrm{CO} 2-\mathrm{DIC}}= & {\left[\mathrm{H}_{2} \mathrm{CO}_{3}\right] * \alpha_{\mathrm{CO} 2-\mathrm{H} 2 \mathrm{CO} 3}+\left[\mathrm{HCO}_{3}\right] * \alpha_{\mathrm{CO} 2-\mathrm{H} 2 \mathrm{CO}-} } \\
& +\left[\mathrm{CO}_{3}{ }^{2-}\right] * \alpha_{\mathrm{CO} 2-\mathrm{CO} 32-}
\end{aligned}
$$

Here in all studied cases as $\mathrm{pH}$ is smaller than $7,\left[\mathrm{CO}_{3}^{2-}\right]$ is smaller than $1 \%$ and can be neglected in (2), in the DIC and alkalinity formulas. The $\mathrm{CO} 2$ degassing causes $\mathrm{pH}$ to rise and the relative abundance of $\left[\mathrm{H}_{2} \mathrm{CO}_{3}\right],\left[\mathrm{HCO}_{3}^{-}\right]$and $\left[\mathrm{CO}_{3}^{2-}\right]$ to change. Consequently the fractionation factor $\alpha_{\mathrm{CO} 2-\mathrm{DIC}}$ gets smaller as $\alpha_{\mathrm{CO} 2-\mathrm{HCO} 3}$ is smaller than $\alpha_{\mathrm{CO} 2-\mathrm{H} 2 \mathrm{CO} 3}$.

Letting $\mathrm{K}_{1}$, be the equilibrium constant between $\mathrm{H}_{2} \mathrm{CO}_{3}$ and $\mathrm{HCO}_{3}^{-}$ and neglecting $\mathrm{K}_{2}$, the equilibrium constant between $\mathrm{HCO}_{3}^{-}$and $\mathrm{CO}_{3}^{2-}$, DIC can be expressed as a function of $\mathrm{HCO}_{3}^{-}$according:

$\mathrm{DIC}=\left[\mathrm{HCO}_{3}{ }^{-}\right]\left(\left[\mathrm{H}^{1}\right] / \mathrm{K}_{1}+1\right)$.

Alkalinity is the sum of the vases relative to the reference state of $\mathrm{H}_{2} \mathrm{O}$ and $\mathrm{H}_{2} \mathrm{CO}_{3}$, for $\mathrm{pH}$ below 9 , it can be reduced to

Alkalinity $=\left[\mathrm{HCO}_{3}{ }^{-}\right]$.

Therefore, along the $\mathrm{CO}_{2}$ degassing path, $\mathrm{pH}$ can be recalculated using Eq. (3) and assuming constant alkalinity (no mineral precipitation nor mineral dissolution):

$\left[\mathrm{H}^{+}\right] \approx($ DIC/alkalinity -1$) \mathrm{K}_{1}$

Thus, inserting this equation into (1) we get,

$\partial^{13} \mathrm{C}_{\mathrm{DIC}} /{ }^{13} \mathrm{C}_{\mathrm{DIC}}=\partial \mathrm{DIC} / \mathrm{DIC}\left(\alpha_{\mathrm{CO} 2-\mathrm{H} 2 \mathrm{CO} 3}+\right.$ Alkalinity $\left./ \mathrm{DIC}\left[\alpha_{\mathrm{CO} 2-\mathrm{HCO}^{-}}-\alpha_{\mathrm{CO} 2-\mathrm{H} 2 \mathrm{CO} 3}\right]\right)$

assuming DIC $\approx{ }^{12} \mathrm{C}_{\mathrm{DIC}}$, the analytical solution is:

$$
\begin{aligned}
& \operatorname{Ln}\left[{ }^{13} \mathrm{C}_{\mathrm{DIC}} /{ }^{13} \mathrm{C}_{\mathrm{DICO}}\right]=\alpha_{\mathrm{CO} 2-\mathrm{H} 2 \mathrm{CO} 3} \mathrm{Ln}\left[\mathrm{DIC} / \mathrm{DIC}^{\mathrm{o}}\right] \\
& + \text { Alkalinity }\left[\alpha_{\mathrm{CO} 2-\mathrm{H}_{2 \mathrm{CO}}-}-\alpha_{\mathrm{CO} 2-\mathrm{H} 2 \mathrm{CO} 3}\right]\left(1 / \mathrm{DIC}^{\mathrm{O}}-1 / \mathrm{DIC}\right)
\end{aligned}
$$

from which a $\delta^{13} C_{D I C}$ value can be computed from any given DIC. Conversely, the original DIC, before degassing $\mathrm{CO}_{2}$, can be computed in order to have an original $\delta^{13} \mathrm{C}_{\mathrm{DIC}}$ consistent with that of measured for $\mathrm{CO}_{2}$ rich samples $(\approx-3.2 \%$ ). For RM3, $\mathrm{CE}, \mathrm{CC}$, and TA (i.e. sample with $\delta{ }^{13} \mathrm{C}_{\mathrm{TDIC}}>-3 \%$ ), the calculated initial TDIC are given in the Table 1.

\subsection{Helium isotopes and heat flux}

The helium isotopes in fluids of La Soufrière have already been investigated to impose new constraints on the ongoing magmatic degassing (Ruzié et al., 2012). The helium isotope data $\left({ }^{3} \mathrm{He} /{ }^{4} \mathrm{He}=\mathrm{R}\right)$ are reported with respect to air $\left(R_{a}\right)$ (where $R_{a}=$ atmospheric ${ }^{3} \mathrm{He} /$ $\left.{ }^{4} \mathrm{He}=1.4 \times 10^{-6}\right)$. By measuring ${ }^{4} \mathrm{He} /{ }^{22} \mathrm{Ne}$ ratios and assuming that the neon is purely derived from air or air saturated water (ASW), the atmospheric He contribution can be corrected and therefore we can calculate the ${ }^{3} \mathrm{He} /{ }^{4} \mathrm{He}_{\mathrm{c}}$ according Eq. (8):

$$
\left({ }^{3} \mathrm{He} /{ }^{4} \mathrm{He}\right)_{\mathrm{c}}=\left[\left({ }^{3} \mathrm{He} /{ }^{4} \mathrm{He}\right)_{\mathrm{m}}-\left({ }^{3} \mathrm{He} /{ }^{4} \mathrm{He}\right)_{\text {air }} * \mathrm{r}\right] /(1-\mathrm{r})
$$

with $\mathrm{r}=\left({ }^{4} \mathrm{He} /{ }^{22} \mathrm{Ne}\right)_{\text {air or asw }} /\left({ }^{4} \mathrm{He} /{ }^{22} \mathrm{Ne}\right)_{\mathrm{m}}$, subscript "c" is the corrected value and " $\mathrm{m}$ " is the measured value. The $\left({ }^{4} \mathrm{He} /{ }^{22} \mathrm{Ne}\right)$ air ratio is 4.81 and $\left({ }^{4} \mathrm{He} /{ }^{22} \mathrm{Ne}\right)_{\mathrm{ASW}}$ is 2.62 , adjusted for He and Ne solubility variations in water and assuming a recharge temperature of $20^{\circ} \mathrm{C}$.
The magmatic signal is clearly recorded in the summit fumarole of CSC $\left[{ }^{3} \mathrm{He} /{ }^{4} \mathrm{He}=8.1 \pm 0.2 \mathrm{R}_{\mathrm{a}, \mathrm{n}=2}\right]$. This ratio is similar to the global MORB range $\left({ }^{3} \mathrm{He} /{ }^{4} \mathrm{He}=8 \pm 1 \mathrm{R}_{\mathrm{a}}\right.$ - Allègre et al., 1995) and previous regional studies of van Soest et al. (1998) and Pedroni et al. (1999). We observe that the Rc/Ra decreases with increasing distance from the dome, except at BJ (Fig. 2B). For this spring, the dilution of the magmatic signal is so significant that no correction can be reasonably applied, suggesting a significant contribution from an atmospheric component. The highest values recorded in the springs closest to the dome are similar to the fumarole value (Table 1 ).

The most radiogenic values are displayed in the most distant springs (HR and CC). Assuming the measured sample is the mixture of mantle and crust components with ${ }^{3} \mathrm{He} /{ }^{4} \mathrm{He}$ ratios of 8.1 and 0.05 Ra respectively, we can calculate the percentage of each component following Eq. (9):

$\mathrm{R}_{\mathrm{C}}=8.1 * \mathrm{X}_{\mathrm{M}}+0.05 *\left(1-\mathrm{X}_{\mathrm{M}}\right)$

with $X_{M}$ as the percentage of magmatic component in the sample. The magmatic component is the dominant component in all the samples $\left(X_{M}=71-100 \%\right)$. Note that two water samples (GUA07-CE and GUA07-RM3) have a corrected ${ }^{3} \mathrm{He} /{ }^{4} \mathrm{He}$ ratio larger than $8.1 \mathrm{Ra}$. We treat them as being derived from $100 \%$ magmatic component.

In order to impose new constraints on the hydrothermal system, we plot the correlation between the magmatic signal $\left(\mathrm{X}_{\mathrm{M}}\right)$ and temperature in the springs (Fig. 4). A clear trend highlights the direct link between both heat and magmatic signal. Two springs do not fit the general trend: (1) the CE spring, which displays a pure magmatic signal $\left(\mathrm{X}_{\mathrm{M}}=100 \%\right)$ and low temperature $\left(20.6^{\circ} \mathrm{C}\right)$ and $(2)$ the BCM spring, with high temperature $\left(58.5^{\circ} \mathrm{C}\right)$ and also a pure magmatic signal $\left(\mathrm{X}_{\mathrm{M}}=100 \%\right)$.

\section{3. $\mathrm{CO}_{2} /{ }^{3}$ He ratio}

The $\mathrm{CO}_{2} /{ }^{3} \mathrm{He}$ is calculated from $\mathrm{He}$ and $\mathrm{TDIC}_{\mathrm{i}}$ contents and the $\left({ }^{3} \mathrm{He} /{ }^{4} \mathrm{He}\right)_{\mathrm{c}}$ ratios. At La Soufrière, $\mathrm{CO}_{2} /{ }^{3} \mathrm{He}$ ratios range from 0.9 to $59 \times 10^{10}$ (Table 1 and Fig. 5). The CSC fumarole $\left(\mathrm{CO}_{2} /{ }^{3} \mathrm{He}=\right.$ $1.03 \pm 0.18 \times 10^{10}, \mathrm{n}=2$ ) displays the lowest measured ratio and is in the arc worldwide range of Sano and Marty, 1995 (1.5 \pm $\left.1.1 \times 10^{10}\right)$. All samples display $\mathrm{CO}_{2} /{ }^{3} \mathrm{He}$ ratio greater than the range of MORB ( $2 \pm 1 \times 10^{9}$, - Marty and Tolstikhin, 1998). This is

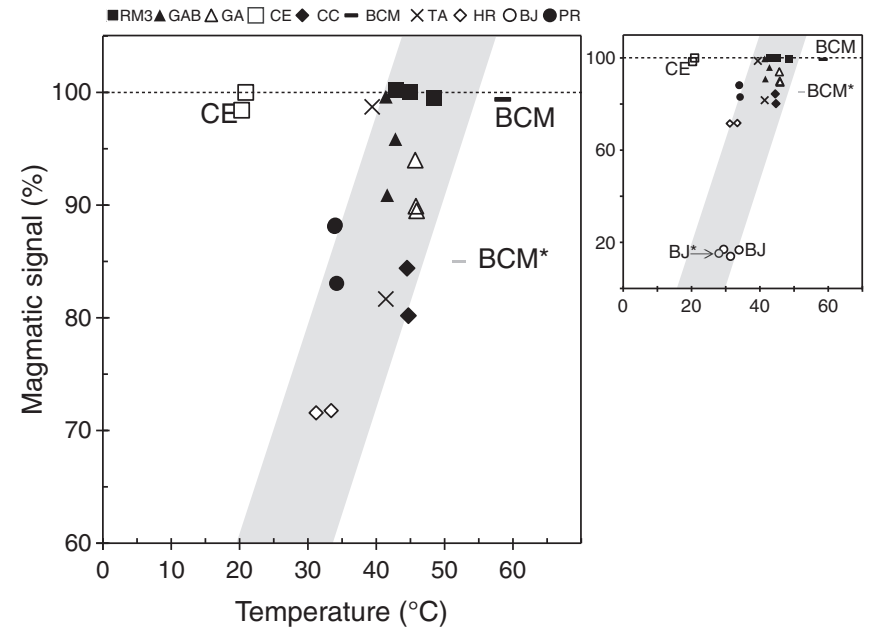

Fig. 4. The magmatic signal vs. in-situ temperature measurements. The grey area highlights a positive trend between both parameters. It emphasizes the direct link existing between heat flux and magmatic flux. CE and BCM springs are clearly decoupled from that trend (see text for more details) *: data from van Soest et al. (1998). 


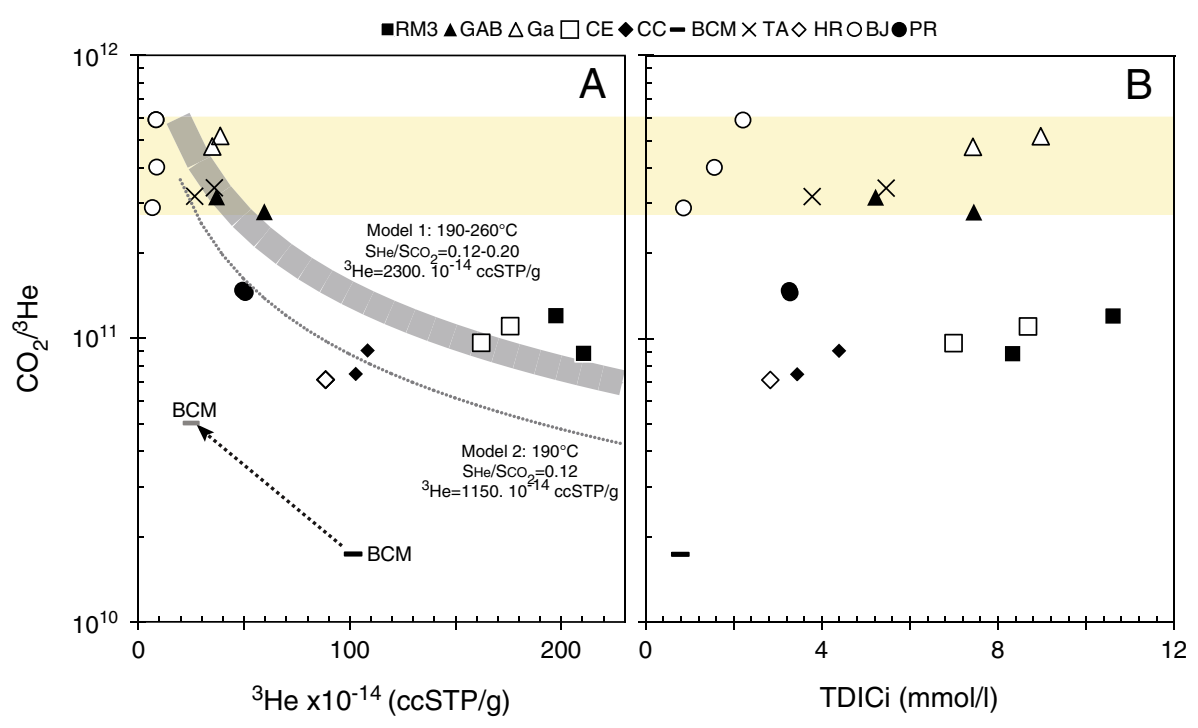

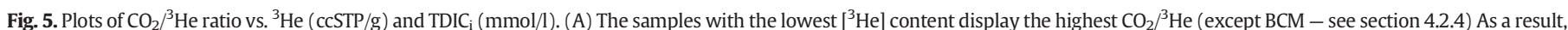

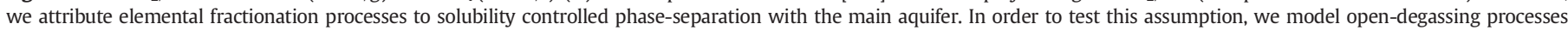

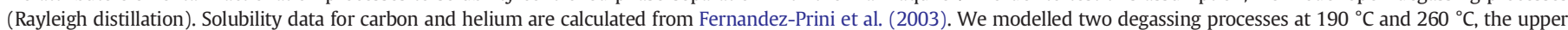

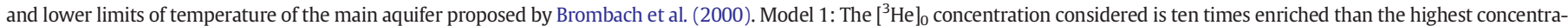

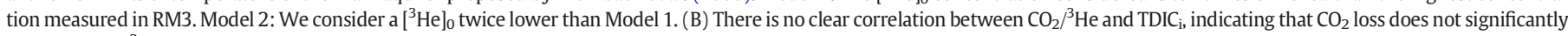
affect the $\mathrm{CO}_{2} /{ }^{3} \mathrm{He}$ values.

presumably due to the addition of either slab-derived carbon (Marty et al., 1989; Sano and Marty, 1995) as discussed later.

The higher ratios are measured in the thermal springs (up to $59 \times 10^{10}, \mathrm{BJ}$ ). The $\mathrm{CO}_{2} /{ }^{3} \mathrm{He}$ ratio of hydrothermal waters does not seem to be related to the summit distance (Fig. 2C), but affected by superficial processes, whose amplitudes may vary from one spring to another. These could be physical/chemical processes, which occur in the hydrothermal system, such as late degassing or dilution (e.g. Barry et al., 2013). Surface contamination (soil, biology) is ruled out by $\delta^{13} \mathrm{C}$ arguments for most of springs with the exception of HR, BCM and BJ (Fig. 3). Finally, the ratio versus ${ }^{3} \mathrm{He}$ concentration and TDIC for all the fluid samples is plotted in Fig. 5. Fluid samples with $<50 \times 10^{-14}$ ccSTP $/ \mathrm{g} \mathrm{H}_{2} \mathrm{O}$ clearly display the highest measured $\mathrm{CO}_{2} /{ }^{3} \mathrm{He}$ values (Fig. 5A). The lack of correlation between $\mathrm{CO}_{2} /{ }^{3} \mathrm{He}$ ratio and TDIC shows that $\mathrm{CO}_{2}$ loss does not affect the elemental ratio (Fig. 5B).

\section{Discussion}

\subsection{The local magmatic end-member at La Soufrière}

The supply of the La Soufrière hydrothermal system with deep magmatic fluids is clearly indicated by the composition of the dissolved gases in the thermal waters. $\mathrm{CO}_{2}$ and helium isotopic data support this hypothesis and reveal that the hydrothermal system is supplied by a $\mathrm{CO}_{2}$-rich magmatic component, sampled by fumaroles $(\mathrm{n}=2)$ with a $\delta^{13} \mathrm{C}_{\mathrm{CO} 2}$ value of $-3.19 \pm 0.03 \%$, a ${ }^{3} \mathrm{He} /{ }^{4} \mathrm{He}$ ratio of $8.1 \pm 0.2 \mathrm{R}_{\mathrm{a}}$ and a $\mathrm{CO}_{2} /{ }^{3} \mathrm{He}$ ratio of $1.03 \pm 0.18 \times 10^{10}$. These values are compared to previous publications in Table 2 (van Soest et al., 1998; Pedroni et al., 1999). No significant changes are recorded since 1995.

Although the helium isotopic data are in the range of MORB, the carbon isotopic signature is higher than the generally accepted MORB range $[-3.68 \pm 0.14 \%$ - Javoy and Pineau, 1991]. However such a ${ }^{13} \mathrm{C}$ value is common in other hydrothermal systems of volcanic arc areas for example, Central Italy (Chiodini et al., 2000), Popocatepetl (Inguaggiato et al., 2005) or in Japan (Sano et Marty, 1995). This ${ }^{13} \mathrm{C}$ positive shift can be explained by the carbon isotope fractionation between $\mathrm{CO}_{2}$ and carbon dissolved in the magma. Such a possibility has been largely demonstrated in MORB where this fractionation is as high as $4 \%$ at $1200{ }^{\circ} \mathrm{C}$ in favour of $\mathrm{CO}_{2}$ (Javoy et al., 1978; Mattey, 1991 and Cartigny et al., 1998). But in arc magmas, due to the lower C solubility in more acidic magmas, the co-degassing of water and the lower temperature and pressure of volatile degassing, a comparatively reduced carbon isotope ${ }^{13} \mathrm{C}$-enrichment of $\mathrm{CO}_{2}$ is expected since most of the carbon initially dissolved in the magma would be degassed as $\mathrm{CO}_{2}$. Consequently the degassed $\mathrm{CO}_{2}$ inherits the $\mathrm{C}$ isotope composition of the initial magma. Only in such circumstances, the $\mathrm{C}$ isotope difference between the $\mathrm{CO}_{2}$ emitted at La Soufrière $(-3.19 \pm 0.03 \%)$ and the "canonical" mantle range $(\sim-4 \%)$ may be interpreted in terms of magmatic source components. A classical approach used to assess carbon provenance at subduction zones is the three-component mixing model of Sano and Marty (1995). We apply this model only for the gas sample because the high-temperature volcanic gases are less affected by elemental and isotopic fractionations than groundwaters, as we will show below. Based on $\mathrm{He}-\mathrm{C}$ characteristics, samples can be described in terms of carbon mixtures derived from three end-members: limestone and/or marine carbonate (including slab carbonates) (L), the mantle (M) and sedimentary organic $C(S)$. Using the following Eqs. (10)-(12), the relative contributions (expressed as fractions, f) from the various sources can be determined:

$$
\begin{aligned}
& \left({ }^{13} \mathrm{C} /{ }^{12} \mathrm{C}\right)_{\text {meas. }}=\left({ }^{13} \mathrm{C} /{ }^{12} \mathrm{C}\right)_{\mathrm{M}} \mathrm{f}_{\mathrm{M}}+\left({ }^{13} \mathrm{C} /{ }^{12} \mathrm{C}\right)_{\mathrm{L}} \mathrm{f}_{\mathrm{L}}+\left({ }^{13} \mathrm{C} /{ }^{12} \mathrm{C}\right)_{\mathrm{S}} \mathrm{f}_{\mathrm{S}} \\
& 1 /\left({ }^{12} \mathrm{C} /{ }^{3} \mathrm{He}\right)_{\text {meas. }}=\mathrm{f}_{\mathrm{M}} /\left({ }^{12} \mathrm{C} /{ }^{3} \mathrm{He}\right)_{\mathrm{M}}+\mathrm{f}_{\mathrm{L}} /\left({ }^{12} \mathrm{C} /{ }^{3} \mathrm{He}\right)_{\mathrm{L}}+\mathrm{f}_{\mathrm{S}} /\left({ }^{12} \mathrm{C}{ }^{12} \mathrm{C} /{ }^{3} \mathrm{He}\right)_{\mathrm{S}} \\
& \mathrm{f}_{\mathrm{M}}+\mathrm{f}_{\mathrm{L}}+\mathrm{f}_{\mathrm{S}}=1
\end{aligned}
$$

taking the $\delta^{13} \mathrm{C}_{\mathrm{CO} 2}$ values of $-4 \%, 0 \%$ and $-30 \%$ for $\mathrm{M}, \mathrm{L}$, and $\mathrm{S}$ and ${ }^{12} \mathrm{C} /{ }^{3} \mathrm{He}$ ratios of $1.5 \times 10^{9}, 1 \times 10^{13}, 1 \times 10^{13}$ for $\mathrm{M}$, L and $\mathrm{S}$, respectively. The carbon isotopic signature and the $\mathrm{CO}_{2} /{ }^{3} \mathrm{He}$ ratio degassed at La Soufrière possibly reflects a mantle contribution of $15 \%$ and a $(L+S)$ contribution of $85 \%(=76 \%+9 \%$, respectively $)$ in the magma source beneath Guadeloupe. These values are in the range determined by van Soest et al. (1998) for the northern part of the Lesser Antilles arc. The calculated ratio $(\mathrm{L}+\mathrm{S}) / \mathrm{M}=5.7$ is within the range of global average for arcs $(6.0 \pm 2.4-$ Sano and Marty, 1995). 
However, the major issue of concern with the methodology of Sano and co-workers is the selection of the end-member values (van Soest et al., 1998; Hilton et al., 2002). For example, the C-isotopic composition of sediments can be altered during subduction (Ohmoto, 1986). A second issue is the role of the superficial contamination by soil or organic matter as illustrated in this study by $\mathrm{HR}\left(\delta^{13} \mathrm{C}_{\mathrm{TDIC}}=-18.11 \%\right)$ and $\mathrm{BCM}\left(\delta^{13} \mathrm{C}_{\mathrm{TDIC}}=-10.04 \%\right.$ ). We will discuss this aspect later.

\subsection{The superficial hydrothermal processes}

\subsubsection{Fumarole and CE spring fed by the vapour phase produced by the boiling aquifer}

We suggest that the summit fumaroles are directly fed by the vapour produced during the boiling of the main aquifer. This suggestion is supported by the noble gas pattern recorded in the CSC fumarole, which indicated mixing between meteoric water at $20{ }^{\circ} \mathrm{C}$ and the local magmatic component (Ruzié et al., 2012).

Considering both the location of CE (altitude $=1146 \mathrm{~m}$ ) and its helium-carbon data $\left({ }^{3} \mathrm{He} /{ }^{4} \mathrm{He}=8.0 \pm 0.1 \mathrm{R}_{\mathrm{a}}\right.$ and $\delta^{13} \mathrm{C}=-2.84 \pm$ $0.03 \%$ ), we propose that the spring might be fed by the same ascending gas as the fumarole, which could partially condense in its small superficial aquifer. However, the temperature and magmatic signal of CE do not fall within the range of our dataset average (Fig. 4). The spring records a pure helium magmatic input $\left(X_{m}=100 \%\right)$ associated with a low temperature (only $20.6{ }^{\circ} \mathrm{C}$ ).

To evaluate the maximum temperature increase in the thermal spring, we have to quantify the heat transfer between rising magmatic gases from the main aquifer and a shallow aquifer. A budget of the heat advectively transported by the gas flux gives an estimate of the maximum temperature increase of the shallow aquifer. We assume that the fumarole gases made of water (95\%), $\mathrm{CO}_{2}$ (3.5\%) and $\mathrm{H}_{2} \mathrm{~S}$ (1.5\%) (Bernard et al., 2006; Bagnato et al., 2009, OVSG-IPGP, 19782012) get totally dissolved into the aquifer water and consequently we are able to compute the quantity of heat released by the cooling of the gas phase from $190^{\circ}-260^{\circ} \mathrm{C}$ to the spring temperature assuming first steam cooling, then steam liquefaction to water, and finally water cooling. Using thermodynamical data (the heat capacity $C_{p}$ for vapour phase $=$ $2.040 \mathrm{kJK}^{-1} \mathrm{~kg}^{-1}$ and that for liquid phase $=4.180 \mathrm{kJK}^{-1} \mathrm{~kg}^{-1}$ ) and the enthalpy of water $(\Delta \mathrm{H}=2,257 \mathrm{~kJ} / \mathrm{kg})$, we get a thermal input of $12 \mathrm{kj}$ in the meteoric water. This energy can heat the water by at max $3{ }^{\circ} \mathrm{C}$. As a consequence the input of magmatic volatiles in spring waters may not be associated with a significant water temperature increase.

\subsubsection{Springs fed by water affected by an open-degassing process}

The residual water of the boiling process that provides the steam to the fumaroles can be mixed with meteoric water in smaller shallow aquifers. It seems that the TA, GA, GAB, PR and RM3 springs could all be the result of this process. To test this assumption, we first modelled the evolution of $\mathrm{CO}_{2} /{ }^{3} \mathrm{He}$ ratio of the residual water during an opensystem degassing process (Fig. 5) using the Rayleigh distillation Eq. (13),

$$
\left(\mathrm{CO}_{2} /{ }^{3} \mathrm{He}\right)_{\text {water }}=\left(\mathrm{CO}_{2} /{ }^{3} \mathrm{He}\right)_{0} * \mathrm{f}^{\left[\left(\mathrm{S}_{\mathrm{He}} / \mathrm{S}_{\mathrm{CO} 2}\right)-1\right]}
$$

where $\mathrm{f}$ is the ratio between $\left[{ }^{3} \mathrm{He}\right]_{\text {water }} /\left[{ }^{3} \mathrm{He}\right]_{0}$. Solubility data for helium $\left(\mathrm{S}_{\mathrm{He}}\right)$ and $\mathrm{CO}_{2}\left(\mathrm{~S}_{\mathrm{CO} 2}\right)$ are calculated at the temperature between $190{ }^{\circ} \mathrm{C}$ and $260{ }^{\circ} \mathrm{C}$ using data from Fernandez-Prini et al. (2003). The $\mathrm{CO}_{2} /{ }^{3} \mathrm{He}$ ratio of CSC fumarole $\left(1.03 \times 10^{10}\right)$ is chosen as representative of deep, non-fractioned gas (Federico et al., 2002). For a degassing of 97$99 \%$, we obtain ratios between 25 and $60 \times 10^{10}$, close to the measured ratios (Fig. 5A). The thermal springs GA, GAB, TA and PR seem to be fed by the residual water of an open degassing process, which is then mixed with small amounts of meteoric water in their respective shallow aquifers.
Using this model, we can see that the water feeding RM3 is less affected by the degassing than the other springs (degassing of $\sim 89 \%$ ). RM3 displays a pure helium magmatic isotopic signal $\left({ }^{3} \mathrm{He} /{ }^{4} \mathrm{He}=8.0\right.$ $\mathrm{R}_{\mathrm{a}}$ ) with low correction for helium $(7 \pm 1 \%)$ and the highest ${ }^{3} \mathrm{He}$ concentration measured in water samples $\left(2.25 \times 10^{-12} \mathrm{ccSTP} / \mathrm{g}\right)$ (Table 1 ). The $\delta^{13} \mathrm{C}$ in 2007 was $-2.11 \%$ and in $2009-3.19 \%$. The latter value is exactly the isotopic value of the summit fumarole. It is difficult to explain the discrepancy between those two values. It could reflect a sampling issue for carbon or the fact that the source was affected by late degassing processes in 2007. The last assumption could also explain the increase of ${ }^{3} \mathrm{He}$ from 1.97 to $2.25 \times 10^{-12}$ ccSTP/ $\mathrm{g}$ between 2007 and 2010. We suggest that this spring could sample water closer to the water of main aquifer, with minimal dilution in term of TDIC and helium by meteoric water and no addition of radiogenic helium.

\subsubsection{Springs affected by mixing processes}

$\mathrm{HR}$ and CC display quite homogeneous $\mathrm{CO}_{2} /{ }^{3} \mathrm{He}$ ratios $(7.2-9.1 \times$ $10^{10}$ ) and ${ }^{3} \mathrm{He}$ concentrations $\left(0.43-1.0 \times 10^{-12} \mathrm{ccSTP} / \mathrm{g}\right.$ ) (Table 1 and Fig. 5A). However, significant variations are observed in the helium and carbon isotopic ratios due to different mixing processes.

The C-isotopic ratio of TDIC for CC displays a signal $\left(\delta^{13} \mathrm{C}_{\mathrm{TDIC}}=\right.$ $-2.84 \pm 0.16 \%$ ) close to magmatic signal and the helium isotopic ratio, $\left({ }^{3} \mathrm{He} /{ }^{4} \mathrm{He}\right)_{\mathrm{c}}=6.6 \pm 0.2 \mathrm{R}_{\mathrm{a}}$ is clearly affected by the addition of radiogenic helium. The addition of ${ }^{4} \mathrm{He}$ could have occurred during water-rock interactions facilitated by a lower ${ }^{3} \mathrm{He}$ input (Fig. 5A) and by a long residence time of water in the shallow aquifer (Ruzié et al., 2012). The residence time has been estimated from tritium data to be about 10 years (Pascaline et al., 1982). This is longer than the average residence time of three months as inferred for the other springs (Pascaline et al., 1982; Bigot et al., 1994a; Villemant et al., 2005).

HR spring has a $\delta^{13} \mathrm{C}_{\mathrm{TDIC}}$ value of $-18.11 \%$ and a helium isotopic ratio of ${ }^{3} \mathrm{He} /{ }^{4} \mathrm{He}=5.7 \pm 0.1 \mathrm{R}_{\mathrm{a}}$. The tritium data do not support a long residence time in that aquifer (Pascaline et al., 1982) and this spring receives a similar ${ }^{3} \mathrm{He}$ input than $\mathrm{CC}$ (Fig. 5A). We assume then the isotopic values of helium are not influenced by the addition of radiogenic helium produced from water-rock interactions. Combining this with the carbon isotopes, we have built a mixing model of two component end-members (organic and magmatic) that could explain the isotopic ratios. We have plotted $\delta^{13} \mathrm{C}$ vs. helium isotope ratio (Fig. 6). Theoretical mixing curves were constructed using $\delta^{13} \mathrm{C}_{\mathrm{TDIC}}=$ $-3.19 \%$ and ${ }^{3} \mathrm{He} /{ }^{4} \mathrm{He}=8.1 \mathrm{R}_{\mathrm{a}}$ for the magmatic end-member and $\delta^{13} \mathrm{C}_{\mathrm{TDIC}}=-29 /-24 \%$ 。 (Rivé et al., 2013) and ${ }^{3} \mathrm{He} /{ }^{4} \mathrm{He}=1$ Ra for the organic end-member. The helium in the organic end-member is assumed to be air-derived (Inguaggiato et al., 2005). The curvature of the mixing line is defined by the ratio $\mathrm{K}=(\mathrm{C} / \mathrm{He})_{\mathrm{mag}} /(\mathrm{C} / \mathrm{He})_{\text {org. }}$. From Fig. 6 , we see that one quarter of the isotopic composition of HR is magmatic $(\mathrm{K}=0.25)$ in relation to its setting far from the dome $(3.7 \mathrm{~km})$. The isotopic signatures of both carbon and helium are therefore strongly influenced by the organic end-member.

\subsubsection{Bains Chauds du Matouba}

BCM thermal spring $(1055 \mathrm{~m}$ ) is located at $1.25 \mathrm{~km}$ from the dome centre, outside the Amic Crater but still within the Grande Découverte Caldera (Fig. 1). The helium signature is magmatic $\left({ }^{3} \mathrm{He} /{ }^{4} \mathrm{He}=8.0 \pm\right.$ $\left.0.8 \mathrm{R}_{\mathrm{a}}\right)$ despite a $\delta^{13} \mathrm{C}$ value $(-10 \%)$ which does not share this characteristic. The $\mathrm{CO}_{2} /{ }^{3} \mathrm{He}$ ratio $\left(2 \times 10^{10}\right)$ is close to that of fumaroles $\left(1.03 \pm 0.18 \times 10^{10}\right)$. This spring also records the highest temperature $\left(58.5^{\circ} \mathrm{C}\right)$ suggesting a new feeding pathway in comparison with other springs (Fig. 4).

Here, our data are compared to a previous study. According to van Soest et al. (1998), the thermal water had a $\mathrm{CO}_{2} /{ }^{3} \mathrm{He}$ ratio of $5 \times 10^{10}$ with a low ${ }^{3} \mathrm{He}$ concentration $\left(0.26 \times 10^{-12} \mathrm{ccSTP} / \mathrm{g}\right)$ and a more radiogenic helium isotopic ratio $\left({ }^{3} \mathrm{He} /{ }^{4} \mathrm{He}=6.8 \mathrm{R}\right.$ ) (Fig. 3). These results differ from the observations made in the present study. 


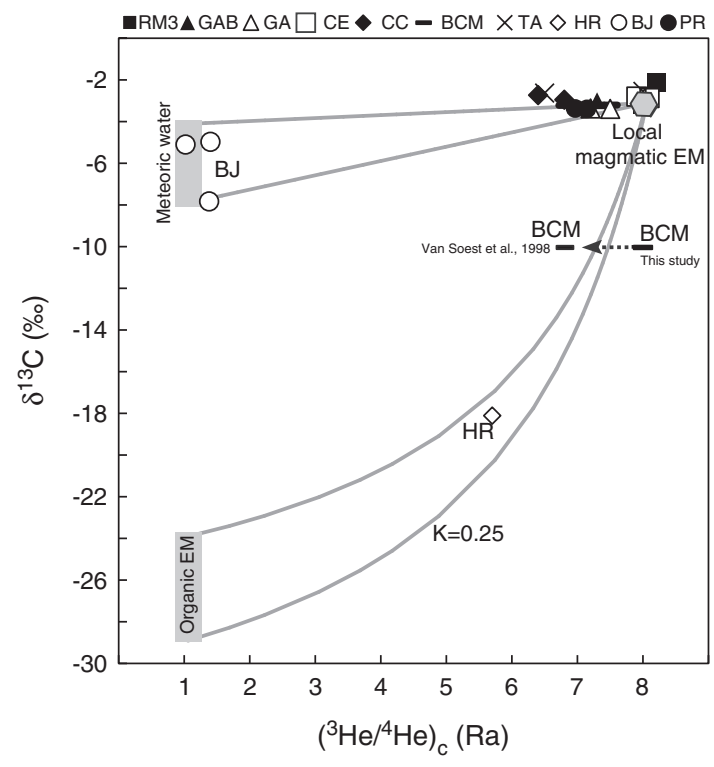

Fig. 6. $\delta{ }^{13} \mathrm{Cvs} .{ }^{3} \mathrm{He} /{ }^{4} \mathrm{He}$ diagram. Combining the helium and carbon isotopic data illustrates that the measured values can be explained by mixing of two end-members. The mixing equation proposed by Langmuir et al. (1978) uses three end-members: magmatic $\left(\delta^{13} \mathrm{C}=-3.19 \%\right.$ and $\left.{ }^{3} \mathrm{He} /{ }^{4} \mathrm{He}=8 \mathrm{R}_{\mathrm{a}}\right)$, meteoric $\left(\delta^{13} \mathrm{C}=-8.6 \%\right.$ and ${ }^{3} \mathrm{He} /{ }^{4} \mathrm{He}=1 \mathrm{R}_{\mathrm{a}}$ or) and organic $\left(\delta^{13} \mathrm{C}=-29-24 \%\right.$ and $\left.{ }^{3} \mathrm{He} /{ }^{4} \mathrm{He}=1 \mathrm{R}_{\mathrm{a}}\right)$. The set of equations was solved by introducing a $\mathrm{K}$ constant, defined as $\mathrm{K}=(\mathrm{C} / \mathrm{He})_{\text {mag }} /(\mathrm{C} / \mathrm{He})_{\text {org. }}$. When $\mathrm{K}=1$, the mixing is a straight line in our diagram. When $\mathrm{K}>1$ or $\mathrm{K}<1$, the mixing line between the two end-members becomes a hyperbola.

In this particular spring, we observe small rising bubbles of $\mathrm{N}_{2}$ (OVSG-IPGP, 1978-2012). As $\mathrm{CO}_{2}$ is 40 times more soluble in water than helium at $58.5^{\circ} \mathrm{C}$ (Fernandez-Prini et al., 2003), the rising N2bubbles concentrate helium, producing an elemental fractionation with $\mathrm{CO}_{2}$. For noble gas measurements, we collected a sample lighter than the others ( $1.95 \mathrm{~g}$ versus an average of $2.20 \mathrm{~g}$ for similar volumes). We therefore think that this gaseous phase was sampled too. This would account for the difference between the measured ${ }^{3} \mathrm{He}$ concentration $\left(1.02 \times 10^{-12} \mathrm{ccSTP} / \mathrm{g}\right)$ and $\mathrm{CO}_{2} /{ }^{3} \mathrm{He}$ compared to those of van Soest et al. (1998). Considering both helium and carbon isotopes (Fig. 6), we observe that the BCM signature can result from the same mixing as the HR spring $(K=0.25)$, with a higher contribution of the magmatic fraction.

Finally, we propose that the small aquifer of this spring could be heated by conduction as suggested by Brombach et al. (2000) and fed by a diffusive flux of gas through fractures. Moreover, this spring seems to be disconnected from the main aquifer, as it has shown no geochemical changes since 1979 (OVSG-IPGP, 1978-2012; Villemant et al., 2005). In the shallow aquifer, a late-stage formation of $\mathrm{N}_{2}$-bubbles could induce late-stage fractionation between $\mathrm{CO}_{2}$ and helium.

\subsection{Implications for volcano monitoring}

Our survey of hydrothermal springs sets a first baseline for helium and carbon concentrations and isotopic variations during the current period of quiescence. Assuming that renewal of volcanic activity at La Soufrière requires partial replenishment of stored volatile-poor andesitic magma by volatile-rich basaltic magma (Ruzié et al., 2012), we argue that a more extensive release of heat, $\mathrm{CO}_{2}$ and helium gases in the shallow hydrothermal system would be triggered by this event. We could expect therefore to measure higher concentrations of these species as well as a temperature increase in both fumaroles and thermal springs. The present study highlights that the fumaroles are probably the most effective way to quickly monitor a change in the magmatic input (Fig. 7). The magmatic volatiles sampled by groundwaters appear to change from their pristine magmatic compositions as a result of various processes such as dilution, solubility-controlled fractionation mechanisms and mixing (Fig. 7). Therefore, springs that are least affected by such superficial processes should be carefully monitored. Based on our investigation, only RM3 spring fulfils these conditions during the present dormancy.

\section{Conclusion}

In this study, we provide a complete baseline of both carbon and helium data of La Soufrière through a systematic geochemical investigation of hydrothermal fluids. We also refine our understanding of the

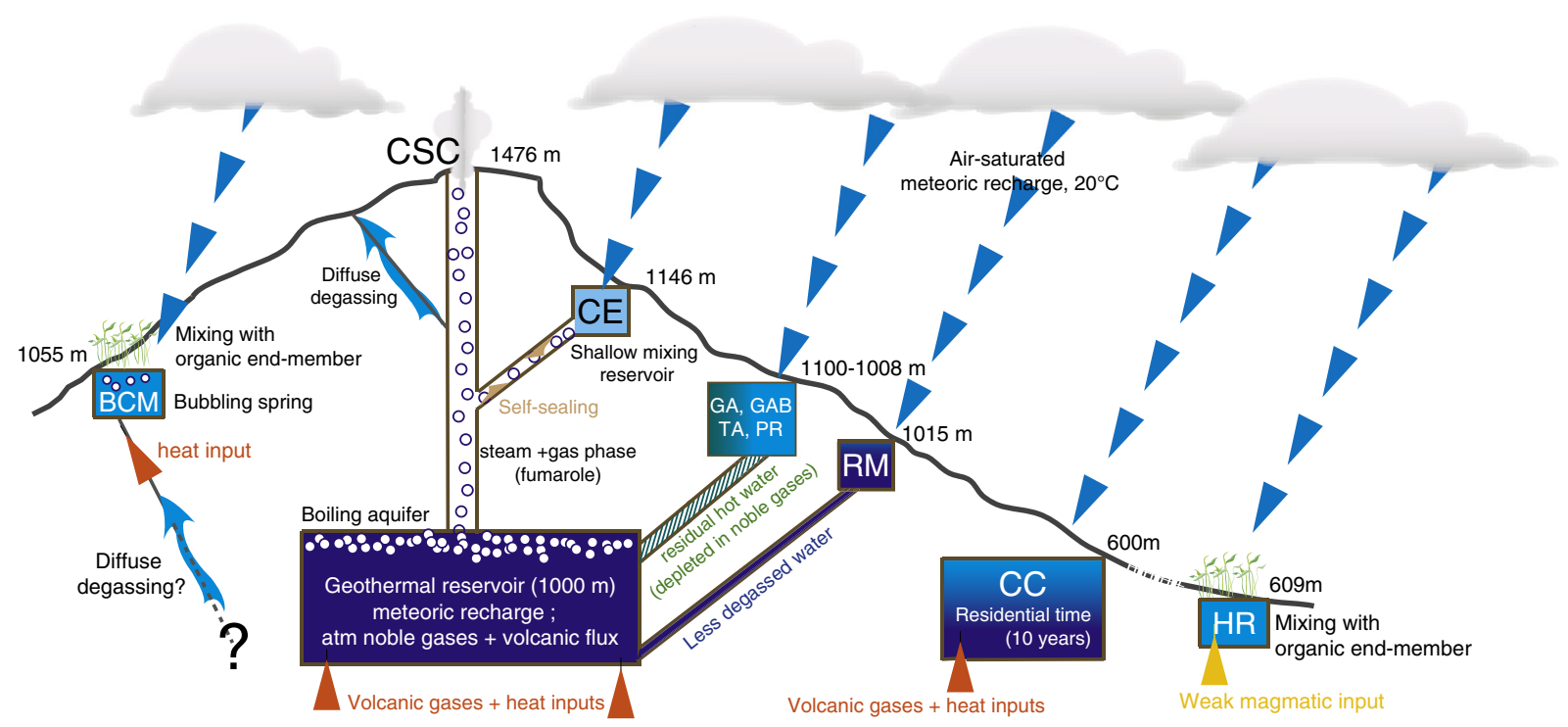

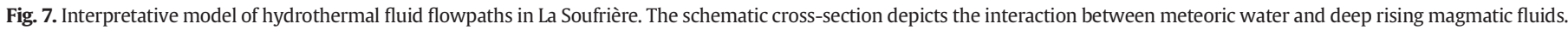

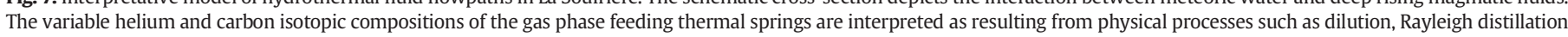
and late degassing. See text for further details. 
Guadeloupe hydrothermal system. Assuming that the chemistry of both helium and carbon is the result of a variable mixture of three components: a deep magmatic gas phase, meteoric water and a contribution of biogenic end-member, we propose how superficial processes affect each spring. The spring waters of La Soufrière can be classified into four groups:

1) thermal springs fed by a mix of meteoric water with residual water of an open-degassing of the main aquifer (GA, GAB, PR, TA, RM3);

2 ) a vapour phase produced by the open-degassing of the main aquifer feeding fumaroles (CSC) or condensing in shallower water table (CE);

3) thermal springs fed by the non-boiling portion of the main aquifer and then submitted to different mixing processes (HR, CC);

4) thermal spring fed by gas diffusing through fractures and affected by late-stage air-bubbles formation (BCM).

\section{Acknowledgements}

The authors would like to thank the members of the OVSG for field missions and continously monitoring teh hydrothermal activity of La Soufrière since 1978. The authors also thank the editor, David Hilton, as well as the two anonymous reviewers for their thorough comments and suggestions. This is IPGP contribution 3437.

\section{References}

Allard, P., Jean-Baptiste, P., D'Alessandro, W., Parello, F., Parisi, B., Flehoc, C., 1997. Mantle-derived helium and carbon in groundwaters and gases of Mount Etna, Italy. Earth Planet. Sci. Lett. 148, 501-516.

Allard, P., Hammouya, G., Parello, F., 1998. Dégazage magmatique diffus à la Soufrière de Guadeloupe, Antilles. C. R. Acad. Sci. de Paris 327, 315-318.

Allègre, C.J., Moreira, M., Staudacher, T., 1995. ${ }^{4} \mathrm{He} /{ }^{3} \mathrm{He}$ dispersion and mantle convection. Geophys. Res. Lett. 22, 2325-2328.

Assayag, N., Rivé, K., Ader, M., Jézéquel, D., Agrinier, P., 2006. Improved method for isotopic and quantitative analysis of dissolved inorganic carbon in natural water samples. Rapid Commun. Mass Spectrom. 20, 2243-2251.

Bagnato, E., Allard, P., Parello, F., Aiuppa, A., Calabrese, S., Hammouya, G., 2009. Mercury gas emissions from La Soufrière Volcano, Guadeloupe Island (Lesser Antilles). Chem. Geol. 266, 267-273.

Barat, A., 1986. Etude du rôle des eaux souterraines dans le mécanisme des éruptions phréatiques. Application à la Montagne Pelée de Martinique et à la Soufrière de Guadeloupe, Document du BRGM. 115.

Barry, P.H., Hilton, D.R., Fischer, T.P., de Moor, J.M., Mangasini, F., Ramirez, C., 2013. Helium and carbon isotope systematics of cold "mazuku"CO2 vents and hydrothermal gases and fluids from Rungwe Volcanic Province, southern Tanzania. Chem. Geol. 339, $141-156$

Bernard, M.-L., Molinié, J., Petit, R.-H., Beauducel, F., Hammouya, G., Marion, G., 2006 Remote and in situ plume measurements of acid gas release from La Soufrière volcano, Guadeloupe. J. Volcanol. Geotherm. Res. 150, 395-409.

Bigot, S., Boudon, G., Semet, M., Hammouya, G., 1994a. Traçage chimique de la circulation des eaux souterraines sur le volcan de la Grande Découverte (la Soufrière) Guadeloupe. C. R. Acad. Sci. IIA - Sci. Terre et des Planètes 319, 1215-1221.

Bigot, S., Boudon, G., Semet, M., Hammouya, G., 1994b. Chemical tracing of groundwater circulation in Grand-Découverte-Volcano (La Soufrière), Guadeloupe. Compte Rendus de l'Académie des Sciences - Series IIA - Earth and Planetary Science 318, $1215-1222$

Boichu, M., Villemant, B., Boudon, G., 2008. A model for episodic degassing of an andesitic magma intrusion. J. Geophys. Res. 113, 18

Boichu, M., Villemant, B., Boudon, G., 2011. Degassing at La Soufrière de Guadeloupe volcano (Lesser Antilles) since the last eruptive crisis in 1975-77: result of a shallow magma intrusion? J. Volcanol. Geotherm. Res. 203, 102-112.

Boudon, G. Semet, M.P. Vincent, P.M. 1989. The evolution of La Grande Découverte (La Soufrière) volcano, Guadeloupe (F.W.I.). In: Latter, J.H. (Ed.), Volcanic Hazards Assessment and Monitoring, IAVCEI Proceedings in Volcanology. Springer-Verlag Berlin Heidelberg, pp. 86-109.

Boudon, G., Komorowski, J.C., Villemant, B., Semet, M.P., 2008. A new scenario for the last magmatic eruption of La Soufrière of Guadeloupe (Lesser Antilles) in 1530 A.D. Evidence from stratigraphy radiocarbon dating and magmatic evolution of erupted products. J. Volcanol. Geotherm. Res. 178, 474-490.

Brombach, T., Marini, L., Hunziker, J.-C., 2000. Geochemistry of the thermal springs and fumaroles of Basse-Terre Island, Guadeloupe, Lesser Antilles. Bull. Volcanol. 61, 477-490.

Cartigny, P., Harris, J.W., Javoy, M., 1998. Eclogitic Diamond Formation at Jwaneng: no room for a recycled component. Science 280, 1421-1424.

Cartwright, I., Weaver, T., Tweed, S., Ahearne, D., Cooper, M., Czapnik, K., Tranter, J., 2002 Stable isotope geochemistry of cold $\mathrm{CO}_{2}$-bearing mineral spring waters, Daylesford Victoria, Australia: sources of gas and water and links with waning volcanism. Chem. Geol. 185, 71-91.
Chiodini, G., Allard, P., Caliro, S., Parello, F., 2000 ${ }^{18} \mathrm{O}$ exchange between steam and carbon dioxide in volcanic and hydrothermal gases: implications for the source of water. Geochim. Cosmochim. Acta 64, 2479-2488.

Deines, P., Langmuir, D., Harmon, R.S., 1974. Stable carbon isotope ratios and the existence of a gas phase in the evolution of carbonate ground waters. Geochim. Cosmochim. Acta 38, 1147-1164

Di Napoli, R., Aiuppa, A., Bellomo, S., Brusc, L., D'Alessandro, W., Candela, E.G., Longo, M., Pecoraino, G., Valenza, M., 2009. A model for Ischia hydrothermal system: evidences from the chemistry of thermal groundwaters. J. Volcanol. Geotherm. Res. 186, 133-159.

Dixon, J.E., Stolper, E.M., 1995. An experimental study of water and carbon dioxide solubilities in mid-ocean ridge basaltic liquids part II: applications to degassing. J. Petrol. 36, 1633-1646.

Federico, C., Aiuppa, A., Allard, P., Bellomo, S., Jean-Baptiste, P., Parello, F., Valenza, M., 2002. Magma-derived gas influx and water-rock interactions in the volcanic aquifer of Mt. Vesuvius, Italy. Geochim. Cosmochim. Acta 66, 963-981.

Fernandez-Prini, R., Alvarez, J.L., Harvey, A.H., 2003. Henry's constants and vapor-liquid distribution constants for gaseous solutes in $\mathrm{H}_{2} \mathrm{O}$ and $\mathrm{D}_{2} \mathrm{O}$ at high temperatures. J. Phys. Chem. Ref. Data 32, 903-916.

Feuillard, M., Allègre, C.J., Brandeis, G., Gaulon, R., Le Mouel, J.L., Mercier, J.C., Pozzi, J.P., Semet, M.P., 1983. The 1975-1977 crisis of la Soufrière de Guadeloupe (F.W.I.): a still-born magmatic eruption. J. Volcanol. Geotherm. Res. 16, 317-334.

Hilton, D., Fischer, T., Marty, B., 2002. Noble gases and volatile recycling at subduction zones. In: Porcelli, D., Ballentine, C.J., Wieler, R. (Eds.), Noble Gases in Geochemistry and Cosmochemistry. Reviews in Mineralogy and Geochemistry, 47. Mineralogical Soc America, pp. 319-370.

Inguaggiato, S., Martin-Del Pozzo, A.L., Aguay, A., Capasso, G., Favara, R., 2005. Isotopic, chemical and dissolved gas constraints on spring water from Popocatepetl volcano (Mexico): evidence of gas-water interaction between magmatic component and shallow fluids. J. Volcanol. Geotherm. Res. 141, 91-108.

Javoy, M., Pineau, F., 1991. The volatiles record of a popping-rock from the Mid-Atlantic Ridge at $14^{\circ} \mathrm{N}$ : chemical and isotopic composition of gas trapped in the vesicles. Earth Planet. Sci. Lett. 107, 598-11.

Javoy, M., Pineau, F., Iiyama, I., 1978. Experimental determination of the isotopic fractionation between gaseous $\mathrm{CO}_{2}$ and carbon dissolved in tholeiitic magma. Contrib. Mineral. Petrol. 67, 35-39.

Komorowski, J-C., Boudon, G., Semet, M., Beauduce, F, Antenor-Habazac, C., Bazin, S. Hammouya, G., 2005. Guadeloupe. In: Lindsay, J.M., Robertson, R.E.A., Shepherd, J.B., Ali, S. (Eds.), Volcanic Atlas of the Lesser Antilles. Seismic Research Unit. The University of teh West Indies, Trinidad, pp. 65-102.

Langmuir, C.H., Vocke, R.D., Hanson, G.N., Hart, H.R., 1978. A general mixing equation with applications to Icelandic basalts. Gunter Faure-Principles of Isotope Geology. Earth Planet. Sci. Lett. 37, 380-392.

Lesparre, N., Gibert, D., Marteau, J., Komorowski, J.C., Nicollin, F., Coutant, O., 2012. Density muon radiography of La Soufrière of Guadeloupe volcano: comparison with geological, electrical resistivity and gravity data. Geophys. J. Int. 190, $1,008-1,019$

Marty, B., Tolstikhin, I.N., 1998. $\mathrm{CO}_{2}$ fluxes from mid ocean ridges, arcs and plumes. Chem. Geol. 145, 233-248.

Marty, B., Jambon, A., Sano, Y., 1989. Helium isotopes and $\mathrm{CO}_{2}$ in volcanic gases of Japan. Chem. Geol. 76, 25-40.

Mattey, D.P., 1991. Carbon dioxide solubility and carbon isotope fractionation in basaltic melt. Geochim. Cosmochim. Acta 55, 3467-3473.

Mook, W.G., Koene, B.K.S., 1975. Chemistry of dissolved inorganic carbon in estuarine and coastal brackish waters. Estuarine and coastal Marine Science 3, 325-336.

Mook, W.G., Bommerson, J.C., Staverman, W.H., 1974. Carbon isotope fractionation between dissolved bicarbonate and gaseous carbon dioxide. Earth Planet. Sci. Lett. $22,169-176$

Négrel, P., Lachassagne, P., Laporte, P., 1997. Caractérisation chimique et isotopique des pluies de Cayenne (Guyane Française). C.R.A.S. 324 (2a), 379-386

Nicollin, F., Gibert, D., Beauducel, F., Boudon, G., Komorowski, J.-C., 2006. Electrical tomography of La Soufrière of Guadeloupe Volcano: field experiments, 1D inversion and qualitative interpretation. Earth Planet. Sci. Lett. 244, 709-724.

Nicollin, F., Gibert, D., Beauducel, F., Boudon, G., Komorowski, J.-C., 2007. Reply to comment on "Electrical tomography of La Soufriere of Guadeloupe Volcano: field experiments, 1D inversion and qualitative interpretation" by $\mathrm{N}$. Linde and A. Revil. Earth Planet. Sci. Lett. 258, 623-626.

Ohmoto, H., 1986. Stable istope geochemistry of hore deposits. Rev. Mineral. 16, 481-559. OVSG-IPGP, 1978-2012. Bilan mensuel de l'Activité volcanique et de la sismisité régionale de l'Observatoire Volcanologique de la Soufrière. http://volcano.ipgp.fr/guadeloupe/Infos.htm.

Pascaline, H., Benauges, S., Jérémie, J.-J., Blavoux, B., 1982. Hydrochimie et circulation des eaux de sources chaudes du massif de la Soufrière Guadeloupe. Bull. Mus. natn. Hist. nat. 4, 137-155

Pedroni, A., Hammerschmidt, K., Friedrichsen, H., 1999. He, Ne, Ar, and C isotope systematics of geothermal emanations in the Lesser Antilles Islands Arc. Geochim. Cosmochim. Acta 63, 515-532.

Poreda, R., Craig, H., 1989. Helium isotope ratio in circum-Pacific volcanic arcs. Nature $338,473-478$.

Rivé, K., Gaillardet, J., Agrinier, P., Rad, S., 2013. Carbon isotopes in the rivers from the Lesser Antilles: origin of the carbonic acid consumed by weathering reactions in the Lesser Antilles. Earth Surf. Process. Landforms 38, 1020-1035.

Ruzié, L., Moreira, M., Crispi, O., 2012. Noble gas isotopes in hydrothermal volcanic fluids of La Soufrière volcano, Guadeloupe, Lesser Antilles arc. Chem. Geol. 304-305, 158-165.

Salaün, A., Villemant, B., Gérard, M., Komorowski, J.C., Michel, A., 2011. Hydrothermal alteration in andesitic volcanoes: trace elements redistribution in active and ancient hydrothermal systems of Guadeloupe (Lesser Antilles). J. Geochem. Explor. 111, 59-83. 
Sano, Y., Marty, B., 1995. Origin of carbon in fumarolic gas from island arcs. Chem. Geol. $119,265-274$.

van Soest, M.C., Hilton, D.R., Kreulen, R., 1998. Tracing crustal and slab contributions to arc magmatism in the Lesser Antilles island arc using helium and carbon relationships in geothermal fluids. Geochim. Cosmochim. Acta 62, 3,323-3,335.

Villemant, B., Hammouya, G., Michel, A., Semet, M.P., Komorowski, J.-C., Boudon, G., Cheminée, J.-L., 2005. The memory of volcanic waters: shallow magma degassing revealed by halogen monitoring in thermal springs of La Soufrière volcano (Guadeloupe, Lesser Antilles). Earth Planet. Sci. Lett. 237, 710-728.
Zlotnicki, J., Boudon, G., Le Mouel, J.-L., 1992. The volcanic activity of La Soufrière of Guadeloupe (Lesser Antilles): structural and tectonic implications. J. Volcanol. Geotherm. Res. 49, 91-104.

Zlotnicki, J., Feuillard, M., Hammouya, G., 1994. Water circulations on La Soufriere volcano inferred from self-potential surveys (Guadeloupe, Lesser Antilles) renew of volcanic activity. J. Geomagn. Geoelectr. 46, 797-813.

Zlotnicki, J., Vargemezis, G., Mille, A., Bruère, F., Hammouya, G., 2006. State of the hydrothermal activity of Soufrière of Guadeloupe volcano inferred by VLF surveys. J. Appl. Geophys. 58, 265-279. 